\title{
A multiproxy approach to reconstruct the environmental changes along the Eurasian continental margin over the last 150000 years
}

\author{
Jochen Knies ${ }^{\mathrm{a}, *}$, Norbert Nowaczyk ${ }^{\mathrm{b}}$, Claudia Müller ${ }^{\mathrm{a}}$, Christoph Vogt ${ }^{\mathrm{c}}$, \\ Ruediger Stein ${ }^{\text {a }}$ \\ ${ }^{a}$ Alfred Wegener Institute for Polar and Marine Research, Columbusstrasse, Bremerhaven, Germany \\ b GeoForschungsZentrum, Telegrafenberg, Potsdam, Germany \\ ${ }^{\mathrm{c}}$ University of Bremen, Klagenfurter Strasse, Bremen, Germany
}

Received 14 August 1998; accepted 20 August 1999

\begin{abstract}
Sediment cores located along the Eurasian continental margin (Arctic Ocean) have been studied to reconstruct the environmental changes in terms of waxing and waning of the Barents/Kara Sea ice-sheets, Atlantic water inflow, and sea-ice distribution over the last $150 \mathrm{kyr}$. The stratigraphy of the cores is based on stable oxygen isotopes, AMS ${ }^{14} \mathrm{C}$, and paleomagnetic data. We studied variations in marine and terrigenous input by a multiproxy approach, involving direct comparison of sedimentological and organo-geochemical data. Extensive episodes of northern Barents Sea ice-sheet growth during marine isotope stages (MIS) 6 and 2 have been supported by, at least, subsurface Atlantic water inflow, moisture-bearing storms, low summer insolation, and minimal calving of ice. Ice advance during MIS 4 was probably restricted to the shallow shelf. Between MIS 4 and MIS 2, large ice-sheet fluctuations correspond to contemporary Laurentide surging events and indicate short-term climatic changes in the Arctic Ocean as has been recorded in lower latitudes. In contrast, in low precipitation areas in eastern Eurasia, glacial activity was rather limited. Only distinct ice-rafted debris (IRD) input during Termination II and early MIS 3 reflects severe glaciations on the northern Severnaya Semlya margin during MIS 6 and MIS 4. We conclude that (1) oscillations of ice-sheets are less frequent along the eastern Eurasian margin than in areas with continuous moisture supply like the western Eurasian margins and that (2) major fluctuations of the Kara Sea ice-sheet during the last $150 \mathrm{kyr}$ apparently followed the major interglacial/glacial MIS 5/4 and MIS 7/6 transitions rather than the precession $(23 \mathrm{kyr})$ and the tilt $(41 \mathrm{kyr})$ cyclicity of the Earth's orbit as observed for the Scandinavian (SIS) and the Svalbard ice-sheets, respectively [Mangerud, J., Jansen, E., Landvik, J.Y., 1996. Late Cenozoic history of the Scandinavian and Barents Sea ice-sheets. In: Solheim, A., Riis, F., Elverhøi, A., Faleide, J.J., Jensen, L.N., Cloetingh, S. (Eds.), Impact of Glaciations on Basin Evolution: Data and Models from the Norwegian Margins and Adjacent Basins. Global and Planetary Chance, Special Issue 12, pp. 11-26.]. Surface and/or subsurface Atlantic water masses coupled with seasonally ice-free conditions penetrated continuously to at least the Franz Victoria Trough during the last 150 kyr. However, sustained periods of open water were largely restricted to substages 5.5, 5.1, and the Holocene as indicated by distinct carbonate dissolution and higher accumulation of marine organic matter (MOM). Signals of periodic open-water conditions along the northern margin of Severnaya Semlya are of less importance. Higher production of foraminifera, probably due to Atlantic water inflow occurred between 38 and $12{ }^{14} \mathrm{C} \mathrm{kyr}$ and corresponds to periodic Atlantic water
\end{abstract}

\footnotetext{
* Corresponding author. Fax: +49-471-4831-580; e-mail: jknies@awi-bremerhaven.de
} 
advection penetrating into the Arctic Ocean. However, marine organic proxies indicate a continuous decrease of surface-water productivity from the western to the eastern Eurasian continental margin due to a more extensive sea-ice cover over the last 150 kyr. (C) 2000 Elsevier Science B.V. All rights reserved.

Keywords: Arctic Ocean; Barents Sea; Kara Sea; Late Quaternary; ice-sheet fluctuation; paleoceanography

\section{Introduction}

Build-up and decay of circum-Arctic ice-sheets, the extension of sea-ice cover and its influence on Earth's albedo, the Nordic Seas thermohaline system, and the Atlantic water circulation are key points for understanding the global climate system (e.g., NAD Science Committee, 1992; Aagaard and Carmack, 1994). However, a critical constraint for environmental reconstructions in the Arctic region is still the stratigraphic resolution of marine and terrestrial records (e.g., Mangerud et al., 1996; Spielhagen et al., 1997; Velitchko et al., 1997a,b; Nørgaard-Pedersen et al., 1998). Therefore, the two major discrepancies concerning the extent and volume of the icesheets along the Eurasian continental margin during glacials have not yet been resolved (e.g., Denton and Hughes, 1981; Dunayev and Pavlidis, 1988; Grosswald, 1993; Pavlidis et al., 1997; Velitchko et al., 1997a,b) and the recently found dynamic coupling of Atlantic water inflow and the Arctic Ocean hydrography (cf. Carmack et al., 1995) could not be classified in Arctic Ocean records (Nørgaard-Pedersen et al., 1998).

However, both aspects are of primary interest for climatic reconstructions because (1) the freshwater supply from the Eurasian ice-sheets may have triggered changes in thermohaline circulation of the North Atlantic (e.g., Oppo and Lehman, 1995) and (2) the seasonal melting of sea-ice caused by intensive inflow of Atlantic water results in distinct changes of the surface albedo, the energy balance, the moisture supply and thus the ocean-ice-atmosphere interaction (e.g., Hibler, 1989; Carmack et al., 1995).

Recently, a few studies documented the connection between the build-up and decay of the Barents /Kara Sea ice-sheets, the outflow of associated meltwater discharge to the central Arctic Ocean, and the inflow of Atlantic water during the last glacial/interglacial cycle (e.g., Hebbeln and Wefer, 1997; Nørgaard-Pedersen et al., 1998; Knies et al.,
1999). Lubinski et al. (1996) and Polyak et al. (1997) showed that the marine-based ice-sheets along the northern Barents Sea margin reached the outer shelf, probably the shelf edge, during the Last Glacial Maximum (LGM). At least, it can be said that based on the amounts of coccoliths and foraminifera during the Late Weichselian the subsurface inflow of Atlantic water and the formation of coastal polynyas, resulting in seasonally open-water conditions had a major influence on the final ice-sheet build-up (cf. Hebbeln et al., 1994; Knies et al., 1999). Major deglaciation of the ice-sheets between 15.4 and 13.3 ${ }^{14} \mathrm{C}$ kyr can be traced in sediments of the central Arctic Ocean and the Fram Strait by $\delta^{18} \mathrm{O}$ meltwater spikes (e.g., Jones and Keigwin, 1988; Stein et al., 1994c; Nørgaard-Pedersen et al., 1998). Glaciomarine sedimentation on the northern Eurasian continental margins induced by insolation and a rise in sea-level, and enhanced Atlantic water inflow at $\sim 13{ }^{14} \mathrm{C}$ kyr has been established (Polyak and Solheim, 1994). However, indications of Atlantic water inflow and build-up/decay of the ice-sheets preceding the last glacial/interglacial cycle are still very rare (Lloyd et al., 1996; Hebbeln and Wefer, 1997; Nørgaard-Pedersen et al., 1998; Knies et al., 1999). Knies and Stein (1998) postulated that paleoceanographic proxies traditionally used in the North Atlantic are of limited value for paleoenvironmental reconstructions on the northern Barents Sea margin. That means that no single proxy can be relied on to give the whole story. Therefore, we tried to elucidate the environmental changes along the Eurasian continental margin over the last $150 \mathrm{kyr}$ with a multiproxy approach. In order to examine the Barents / Kara Sea ice-sheet build-up and decay we studied the lithology, the input of ice-rafted debris (IRD), the clay mineralogy, and the bulk accumulation rates in two cores, which are located northeast of Svalbard, and northeast of Severnaya Semlya (Fig. 1). Information regarding the paleoceanography along the Eurasian continental margin were achieved by determining bulk organic carbon analysis, biogenic and 


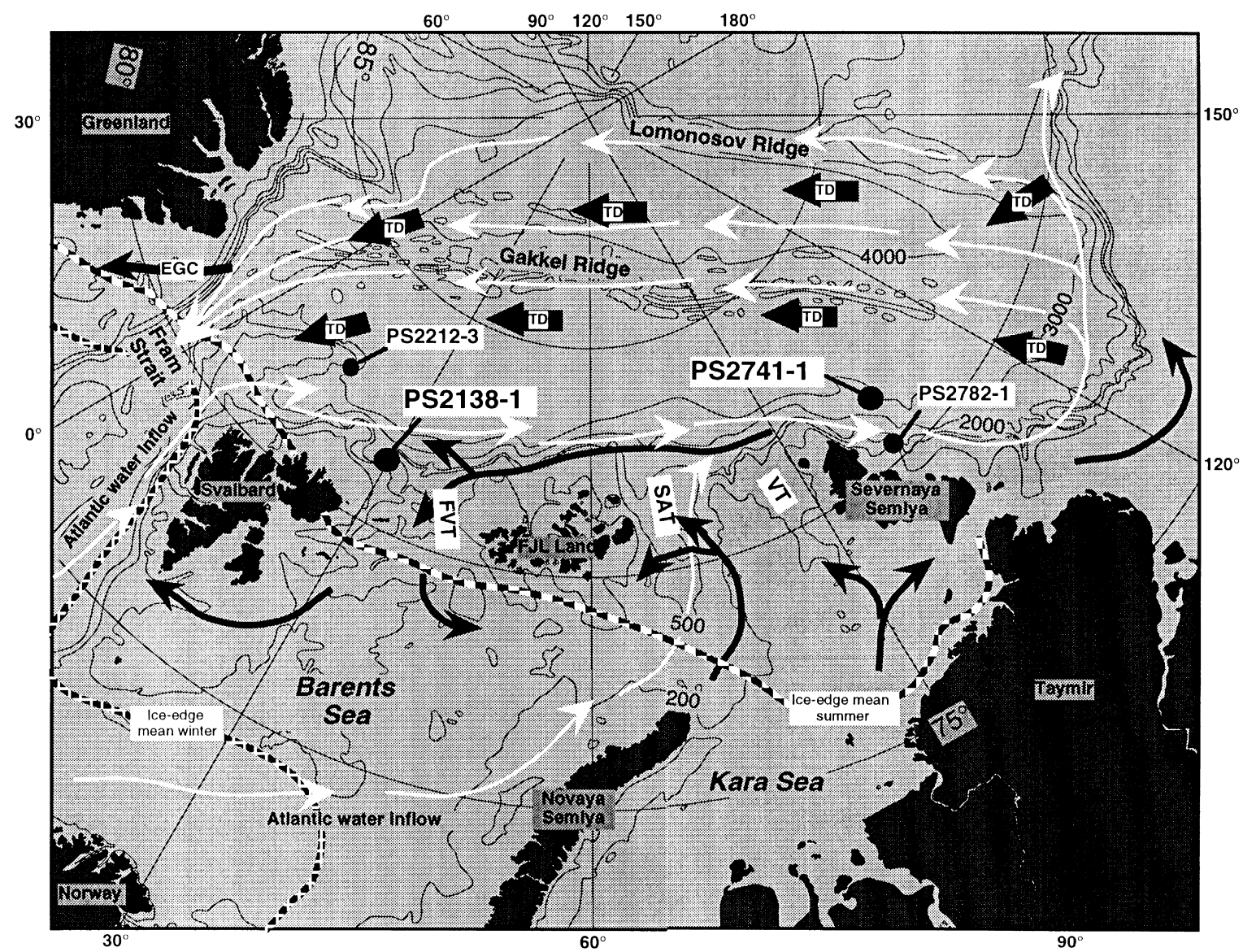

Fig. 1. The main oceanographic setting in the eastern sector of the Arctic Ocean after Aagaard and Carmack (1994). Bathymetry and core sites discussed in this study are shown. Note that PS2212-3 were only used to establish chronology of PS2741-1. Average ice conditions are adopted from Sudgen (1982). White arrows denote inflow of surface and intermediate Atlantic derived water masses according to Rudels et al. (1994). Black arrows mark modern sea-ice drift paths. Abbreviations are FJ Land: Franz Josef Land; TD: Transpolardrift; EGC: East Greenland Current; FVT: Franz Victoria Trough; SAT: St. Anna Trough; VT: Voronin Trough.

detrital carbonate, and several marine and terrigenous-derived biomarkers. We show that the intercorrelation of those proxies, including specific organic compounds, elucidate glacial and interglacial paleoclimatic variations along the Eurasian continental margin over the last $150 \mathrm{kyr}$.

\section{Oceanographic setting}

The present-day current pattern in the eastern Arctic Ocean is dominated by the interaction of Atlantic water inflow from the Norwegian Sea through Fram Strait and over the Barents and Kara seas with its counterpart, the Transpolar Drift (TD) and the East Greenland Current (EGC), with their cold, low-saline polar water outflow (Aagaard and Carmack, 1989, 1994; Meincke et al., 1997). The permanent sea-ice cover in the central Arctic Ocean caused by high river runoff and net precipitation is mainly controlled by the interaction of warm Atlantic and cold polar water masses (Vinje, 1977, 1985). The TD system governs the overall motion of sea-ice in the eastern Arctic Ocean and leads to a movement of sea-ice away from the Siberian coast, across the Arctic basin, and south through the western side of the Fram Strait. The Atlantic water is transformed and exported into high density interme- 
diate waters after entering the Arctic Ocean. These Atlantic water-derived intermediated water masses flow eastward along the Eurasian continental slope (Fig. 1). According to Schauer et al. (1997), the Atlantic layer is largely decoupled from the atmosphere, and its main transformations occur through interactions with plumes of dense water ejected by seasonal sea-ice production on the shallow Barents and Kara Sea shelves. In the Eurasian Basin, a tight loop brings the water back towards the Fram Strait following the Lomonosov and Gakkel Ridge. In the Fram Strait, the Arctic Ocean intermediate outflow in the EGC encounters the recirculating water of the relatively warm West Spitsbergen Current (WSC).

\section{Materials and methods}

The three sediment cores studied were located along the Eurasian continental margin and were recovered during two expeditions with $\mathrm{R} / \mathrm{V} \mathrm{Po}$ larstern (Fig. 1, Table 1) (Rachor, 1992, 1997). All cores were routinely sampled at $5-10 \mathrm{~cm}$ intervals; additional samples were taken in intervals of changing lithology and/or color. Lithological characteristics and IRD contents were determined by evaluation of X-radiographs (e.g., Grobe, 1987). All cores consist mainly of bioturbated mud, with occasional laminated sequences and layers of sand and gravel (cf. Fig. 4). The sediment color varies between brownish and dark olive.

\subsection{Bulk analysis}

For bulk analysis, $5 \mathrm{~cm}^{3}$ samples were taken, freeze-dried and homogenized. Total carbon (TC) and total organic carbon (TOC) were determined using a Heraeus $\mathrm{CHN}$-analyzer. The carbonate content was calculated as $\mathrm{CaCO}_{3}(\%)=(\mathrm{TC}-$

Table 1

Site locations and water depth of the investigated cores

\begin{tabular}{lllcl}
\hline Core & Latitude & Longitude & $\begin{array}{l}\text { Water } \\
\text { depth }(\mathrm{m})\end{array}$ & Core type \\
\hline PS2212-3 & $82^{\circ} 04.2 \mathrm{~N}$ & $15^{\circ} 43.0 \mathrm{E}$ & 2550 & Kasten corer \\
PS2138-1 & $81^{\circ} 32.1 \mathrm{~N}$ & $30^{\circ} 35.6 \mathrm{E}$ & 995 & gravity corer \\
PS2741-1 & $81^{\circ} 06.3 \mathrm{~N}$ & $105^{\circ} 23.6 \mathrm{E}$ & 2530 & Kasten corer \\
PS2782-1 & $79^{\circ} 36.6 \mathrm{~N}$ & $103^{\circ} 21.3 \mathrm{E}$ & 340 & gravity corer \\
\hline
\end{tabular}

TOC) $* 8.333$ (for details concerning the method, see Stein, 1991). The dolomite content was measured by means of a Philips PW3020 diffractometer and determined using the Qualit software package described in detail by Emmermann and Lauterjung (1990) and Vogt (1997). The hydrogen index (HI in mg hydrocarbon (HC)/g TOC) was achieved by means of Rock Eval pyrolysis as described by Espitalié et al. (1977). For clay mineralogy, the fraction $<2 \mu \mathrm{m}$ was separated by wet sieving and the Stoke's law settling method in Atterberg tubes. The measurements were carried out on a Philips PW1820 diffractometer with an automatic divergence slit, using $\mathrm{CoK} \alpha$ radiation $(40 \mathrm{kV}, 40 \mathrm{~mA})$. Identification of clay minerals was done at $17 \AA$ for smectite and $7 \AA$ for kaolinite and chlorite (see Vogt, 1997 for more details). Relative clay-mineral contents were calculated by using empirical factors after Biscaye (1965) and normalized to $100 \%$.

Samples for magnetostratigraphic analyses were taken every $2-3 \mathrm{~cm}$ with $6.2 \mathrm{~cm}^{3}$ cubic plastic boxes. Remanence measurements and progressive alternating field demagnetization were performed with a fully automated, DC-SQUID-based 2G 755 SRM at the GeoForschungsZentrum Potsdam. Determination of characteristic remanent magnetization and polarity was based on principle component analysis of all samples. A detailed presentation of the paleo- and rock magnetic results will be published elsewhere (Nowaczyk and Knies, 1999). Magnetic susceptibility was measured directly on the split surface of the cores applying the Bartington MS2F (PS2212-3) and MS2E (PS2741-1) high resolution sensors, respectively (for details concerning the logging technique, see Nowaczyk and Antonow, 1997).

\subsection{Biomarker analysis}

The analytical procedure used for the determination of $n$-alkanes and chlorins are described in detail in Fahl and Stein $(1997 ; 1999)$ and Knies and Stein (1998). Briefly, approximately 2-3 g freeze-dried and homogenized sediment was extracted with methanol and dichloromethane. An aliquot of the total extract was used for analyzing $n$-alkanes. The $n$-alkane-fraction was separated by column chromatography with hexane.

The $n$-alkanes were analyzed by gas chromatography (HP 5890) with a flame ionization detector and a 
Table 2

Results of AMS ${ }^{14} \mathrm{C}$

\begin{tabular}{|c|c|c|c|c|c|}
\hline Core & $\begin{array}{l}\text { Depth in } \\
\text { core (cmbsf) }\end{array}$ & Material & Reservoir corr. ${ }^{14} \mathrm{C}$ ages & Calendar ages & $\begin{array}{l}\text { Laboratory } \\
\text { reference no. }\end{array}$ \\
\hline PS2138-1 & 80 & bivalves & $12600+140 /-130$ & 14796 & KIA363 \\
\hline PS2138-1 & 110 & mixed forams & $13590+80 /-80$ & 16294 & KIA4765 \\
\hline PS2138-1 & 130 & mixed forams & $15410+130 /-130$ & 18325 & KIA1283 \\
\hline PS2138-1 & 160 & N. pachyderma $\sin$. & $16230+210 /-210$ & 19111 & KIA364 \\
\hline PS2138-1 & 200 & N. pachyderma $\sin$. & $16880+130 /-130$ & 20573 & KIA2745 \\
\hline PS2138-1 & 300 & N. pachyderma sin. & $20040+330 /-320$ & 23700 & KIA365 \\
\hline PS2138-1 & 331 & N. pachyderma $\sin$. & $23100+240 /-240$ & 27185 & KIA2744 \\
\hline PS2138-1 & 360 & bivalves & $25800+280 /-270$ & 30161 & KIA4766 \\
\hline PS2138-1 & 380 & mixed forams & $34900+1570 /-1310$ & 34900 & KIA1284 \\
\hline PS2741-1 & 160 & mixed forams & $11600+70 /-70$ & 13527 & KIA4764 \\
\hline PS2741-1 & 200 & N. pachyderma sin. & $37720+3500 /-2500$ & 37720 & KIA0110 \\
\hline PS2782-1 & 338 & mixed forams & $>44140$ & & KIA2746 \\
\hline
\end{tabular}

cold injection system (Gerstel). Helium was used as carrier gas. The $n$-alkanes were identified with authentic standards and were quantified by an internal standard (Squalane). Results are expressed as micrograms per gram dry weight sediment.

The chlorophyll-derived pigments (chlorins) were determined by measuring the absorbance of their solvent extracts (extraction in $90 \%$ acetone) at a wavelength of $665 \mathrm{~nm}$ (more details in Rosell-Melé et al., 1997). The turbidity factor at $750 \mathrm{~nm}$ was subtracted and normalized to dry weight sediment.

\subsection{Stable isotope analysis}

Stable carbon isotope ratios of the organic fraction were determined on decarbonated samples using a Finnigan MAT Delta-S mass spectrometer (AWI, Potsdam). Accuracy was checked by parallel analysis of international standard reference material (IAEACH-7). Results are expressed in \%o vs. Vienna-PDB. A Finnigan MAT 251 mass spectrometer (AWI, Bremerhaven) was used to perform stable oxygen and carbon isotope measurements on the planktonic foraminifer Neogloboquadrina pachyderma sin. from the $>63 \mu \mathrm{m}$ fraction. Results are expressed in the $\delta$-notation (\%o vs. PDB) and are calibrated against the National Institute of Standards and Technology (NIST) 19 standards.

\subsection{AMS ${ }^{14} \mathrm{C}$ dating and bulk accumulation rate}

Several samples were chosen for accelerator mass spectrometry (AMS) ${ }^{14} \mathrm{C}$ dating (Leibniz Laboratory,
Kiel University) (cf. Table 2). The ${ }^{14} \mathrm{C}$ dates are $\delta^{13} \mathrm{C}$-normalized and corrected for reservoir effects equal to 440 years (Mangerud and Gulliksen, 1975). Calendar years (BP) are calculated using the program Calib 3.0 (Stuiver and Reimer, 1993) for ages $<18{ }^{14} \mathrm{C}$ kyr. Dates older than $>18{ }^{14} \mathrm{C}$ kyr were corrected using the equation from Bard et al. (1992): calendar years $(\mathrm{BP})=\left[-5.85 \times\left(10^{-6}\right) \times\left({ }^{14} \mathrm{C}\right.\right.$ age $\left.)^{2}\right]+\left[1.39 \times\left({ }^{14} \mathrm{C}\right.\right.$ age $\left.)-1807\right]$. When not specified as ${ }^{14} \mathrm{C}$ ages, given ages are calendar ages.

Bulk mass accumulation rates $\left(\mathrm{AR}_{\text {bulk }}\right)$ were calculated as the product of the dry bulk density and the linear sedimentation rates (LSR) calculated from the interpolated calendar ages for each sample (Van Andel et al., 1975). Dry bulk density for PS2138-1 was determined by weighing $5 \mathrm{~cm}^{3}$ of dry sediment, measuring volume and density by Accupyc1330 (Micromeritic), and calculating wet bulk density and porosity according to Gealy (1971). Dry bulk density data for PS2741-1 were adopted from N. NørgaardPedersen (unpublished data). The accuracy and reproducibility of all described methods are outlined in Nowaczyk and Antonow (1997), Vogt (1997) and Knies and Stein (1998).

\section{Stratigraphy}

The sediment records along the Eurasian continental margin cover marine isotope stage (MIS) 6 to the Holocene (Figs. 2 and 3). The age model of PS2138-1 is based on the correlation of the stable 


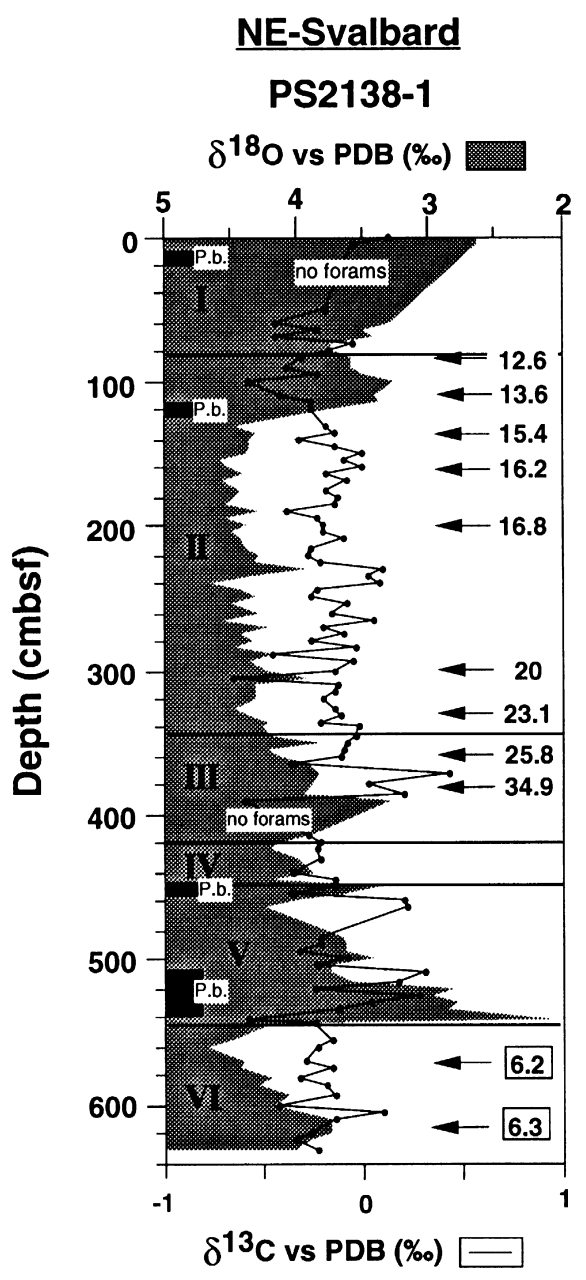

Fig. 2. Oxygen and carbon isotope stratigraphy, and AMS ${ }^{14} \mathrm{C}$ datings of PS2138-1 vs. depth (cmbsf). MIS stages are displayed. Abundances of $P$. bulloides (PB) are marked by solid bars (J. Wollenburg, unpublished data). MIS events 6.2 and 6.3 are indicated (cf. Martinson et al., 1987).

oxygen isotope records of the planktonic foraminifer $N$. pachyderma sin. with the chronostratigraphy of Martinson et al. (1987) (Fig. 2) (cf. Knies et al., 1999). The stratigraphical control is further modified by several radiocarbon (AMS ${ }^{14} \mathrm{C}$ ) datings (Fig. 2).
Beyond the range of ${ }^{14} \mathrm{C}$ datings, the final chronology has been supported by the carbon isotope record, the occurrences of the benthic foraminifer Pullenia bulloides during substage 5.1 and between substages 5.5 and 5.3 (Haake and Plaumann, 1989; Haake et al., 1990), and the identification of MIS events 6.2 and 6.3 according to Martinson et al. (1987) (Fig. 2).

The age model of PS2741-1 was established by AMS ${ }^{14} \mathrm{C}$ datings and paleomagnetic data (Fig. 3). Investigations of sediments from the northern high latitudes yielded increasing evidence that the geomagnetic Brunhes Chron has been interrupted by a series of short excursions and polarity events (Bleil and Gard, 1989; Løvlie, 1989a,b; Løvlie et al., 1986; Schneider et al., 1996; Nowaczyk and Antonow, 1997; Nowaczyk et al., 1994). In our study, we use these geomagnetic events as additional chronostratigraphic markers in order to obtain further fixpoints for the age model of PS2741-1. The AMS ${ }^{14} \mathrm{C}$ age of $11.6 \mathrm{kyr}$ at $160 \mathrm{cmbsf}$ reflects the MIS 2/1 boundary. The Mono Lake event (cf. Denham and Cox, 1971) dated in PS2138-1 $\left(23-20{ }^{14} \mathrm{C} \mathrm{kyr}\right.$ ) (cf. Nowaczyk and Knies, 1999) is identified in PS2741-1 between 188 and 181 cmbsf. The Laschamp event (Bonhommet and Babkine, 1967) dated in sediment records from the Yermak Plateau and the Arctic Ocean (43-34 kyr) (Nowaczyk and Baumann, 1992; Nowaczyk et al., 1994) is identified in PS2741-1 between 192 and $227 \mathrm{cmbsf}$, and correlates well with AMS ${ }^{14} \mathrm{C}$ age of $37.7 \mathrm{kyr}$ at $200 \mathrm{cmbsf}$ (Fig. 3).

The distinct IRD layer at $264 \mathrm{cmbsf}$ reflects the Middle Weichselian deglaciation at the MIS 4/3 transition (cf. Hebbeln, 1992; Mangerud et al., 1998). Nørgaard-Pedersen et al. (1998) correlate this major deglaciation event in the central Arctic Ocean with isotope event 3.31 (55.5 kyr) (Martinson et al., 1987). We suggest that the increased IRD input at the northern margin of Severnaya Semlya also corresponds to isotope event 3.31 and marks the MIS 4/3 transition in this region.

In PS2212-3, two polarity events with negative inclinations are documented in MIS 5 (Fig. 3)

Fig. 3. Correlation of PS2741-1 from the northern Severnaya Semlya margin to PS2212-3 from the Yermak Plateau (Nowaczyk et al., 1994) by means of magnetic susceptibility and inclination of the characteristic remanent magnetization (IChRM). Closed diamonds and numbers indicate results of AMS ${ }^{14} \mathrm{C}$ datings (cf. Table 2). Layers with higher contents of IRD in PS2741-1 are marked by grey bars (cf. Fig. 5b). Geomagnetic events are labelled as: ML: Mono Lake, La: Laschamp, NGS: Norwegian-Greenland Sea, Bl: Blake. 


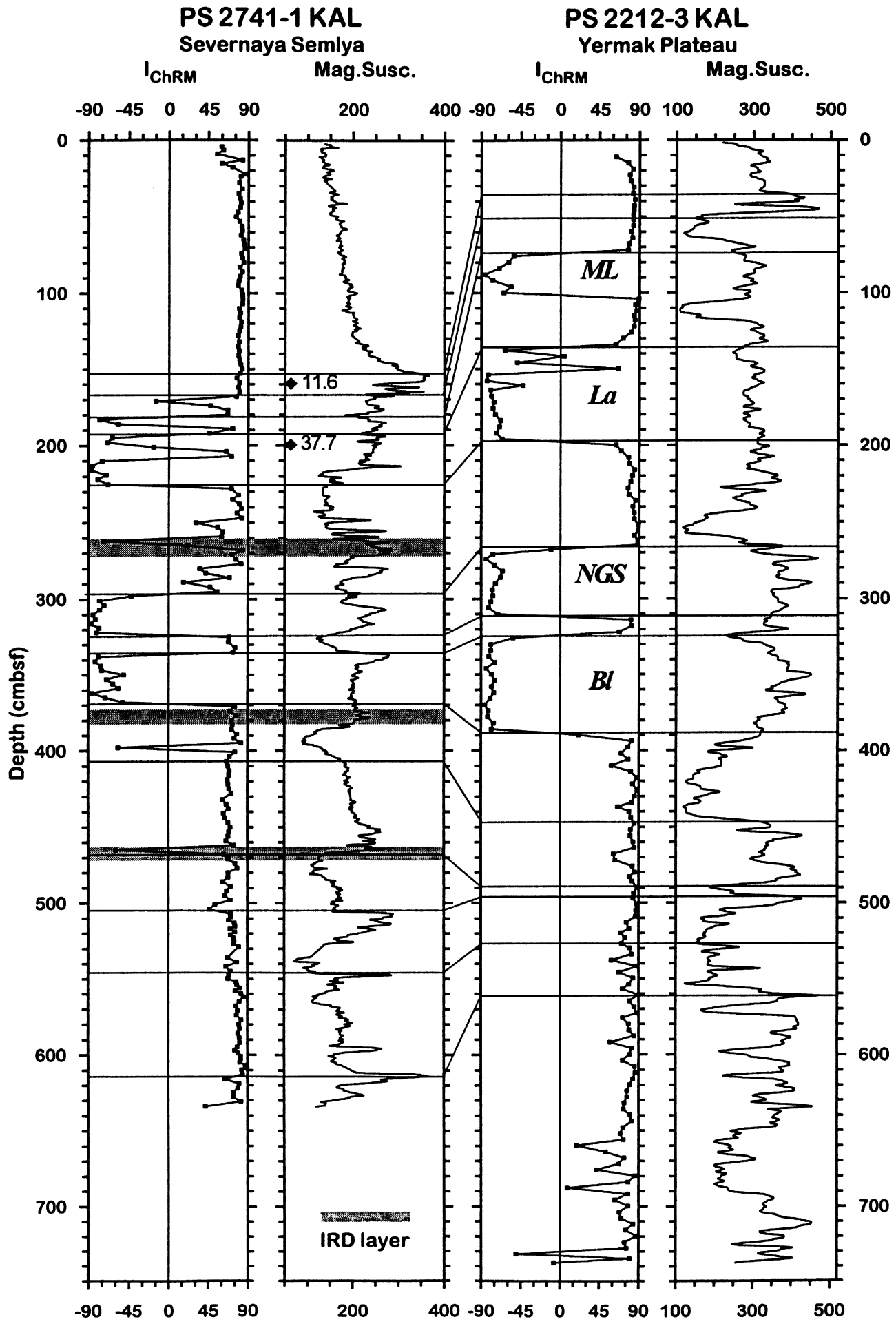


Table 3

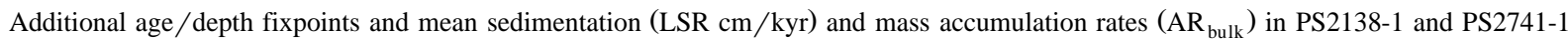

\begin{tabular}{|c|c|c|c|c|}
\hline $\begin{array}{l}\text { PS2138-1 core } \\
\text { depth }(\mathrm{cm})\end{array}$ & $\begin{array}{l}\text { Age-fixpoint calendar } \\
\text { years }^{\text {a }}(\mathrm{kyr})\end{array}$ & Indication & $\begin{array}{l}\text { Mean LSR } \\
(\mathrm{cm} / \mathrm{kyr})\end{array}$ & $\begin{array}{l}\text { Mean } \mathrm{AR}_{\text {bulk }} \\
\left(\mathrm{g} \mathrm{cm}^{-2} \mathrm{kyr}^{-1}\right)\end{array}$ \\
\hline 0 & Recent $^{b}$ & & & \\
\hline 80 & 14.8 & AMS ${ }^{14} \mathrm{C}$ & 5.4 & 9.0 \\
\hline 345 & 28.2 & MIS $2 / 3$ & 21.2 & 42.8 \\
\hline 420 & 59.0 & MIS $3 / 4$ & 4.4 & 6.7 \\
\hline 450 & 74.0 & MIS $4 / 5$ & 2.0 & 3.2 \\
\hline 545 & 130.0 & MIS 5/6 & 1.7 & 2.9 \\
\hline 560 & 135.0 & Event $6.2^{\mathrm{c}}$ & 3.0 & 4.8 \\
\hline 610 & 142.0 & Event $6.3^{c}$ & 7.1 & 12.2 \\
\hline
\end{tabular}

PS2741-1 (cm)

\begin{tabular}{rllrl}
\hline 0 & Recent $^{\mathrm{b}}$ & & & \\
160 & 13.5 & AMS ${ }^{14} \mathrm{C}$ & 11.8 & 1.9 \\
200 & 37.7 & AMS ${ }^{14} \mathrm{C}$ & 1.6 & 3.4 \\
227 & 43.0 & (Base) Laschamp & 5.1 & 3.8 \\
268 & 55.5 & Event 3.31 & 3.3 & 1.6 \\
295 & $72.0^{\mathrm{d}}$ & (Top) NGS & 1.6 & 1.5 \\
324 & $86.0^{\mathrm{d}}$ & (Base) NGS & 1.9 & 0.4 \\
335 & $118.0^{\mathrm{d}}$ & (Top) Blake & 3.4 & 2.5 \\
369 & $128.0^{\mathrm{d}}$ & (Base) Blake & 3.4 & \\
\hline
\end{tabular}

${ }^{\mathrm{a}}$ Further AMS ${ }^{14} \mathrm{C}$ age-fixpoints for core PS2138-1 are outlined in Table 2.

${ }^{\mathrm{b}}$ Assumed.

${ }^{\mathrm{c}}$ According to Martinson et al. (1987).

${ }^{\mathrm{d} A c c o r d i n g}$ to Nowaczyk et al. (1994).

(Nowaczyk et al., 1994): The Norwegian-Greenland Sea (NGS) event (Bleil and Gard, 1989) within the late MIS 5, and the Blake event (Smith and Foster, 1969) within the early MIS 5. This assignment was proven by the occurrence of the benthic foraminifera $P$. bulloides at the top of the NGS event (MIS 5/4 boundary) (J. Wollenburg, personal communication) and by correlation of the stable isotope records of PS2212-3 and the well-dated nearby core PS1533-3 (cf. Köhler and Spielhagen, 1992; Nowaczyk et al., 1994; Vogt, 1997). In PS2741-1, both events could be identified between 295-324 (NGS) and 335-369 cmbsf (Blake), respectively (Fig. 3). Calcareous nannofossil biostratigraphy, oxygen isotope data, and ${ }^{10}$ Be-stratigraphy of two cores from the Yermak Plateau (PS2212-3 and PS1533-3) yielded age ranges of $\sim 72-86 \mathrm{kyr}$ for the NGS event and $\sim 118-128$ kyr for the Blake event (Nowaczyk et al., 1994). Despite the uncertainties to obtain absolute ages for the geomagnetic events in MIS 5 (cf. Table 5 in Nowaczyk et al., 1994) and no further age fixpoints in MIS 6 and early MIS 5, we assume that the distinct IRD layer at $380 \mathrm{cmbsf}$ reflects the final
Saalian-deglaciation at the MIS 6/5 transition (Termination II) (Mangerud et al., 1998). The age of the core base of PS2741-1 is not known directly, but by correlating lithology and the susceptibility logs of both cores PS2212-3 and PS2741-1, we tentatively estimate the depth/age relationship for the older sediments (Fig. 3). However, sufficient stratigraphic information to define the age model for MIS 6 in PS2741-1 more precisely are not available, which prevented a detailed interpretation of environmental changes in that time period. Nevertheless, we used all available age control points in PS2741-1 (MIS 5-1) and PS2138-1 (MIS 6-1) to reveal a preliminary view of mean $L S R$ and $\mathrm{AR}_{\text {bulk }}$ during glacials and interglacials along the Eurasian continental margin (cf. Table 3).

\section{Results}

\subsection{Sedimentation and mass accumulation rates}

The mean LSR and $\mathrm{AR}_{\text {bulk }}$ values along the Eurasian continental margin vary between 0.4 and 
$21.2 \mathrm{~cm} / \mathrm{kyr}$ and 0.4 and $42.8 \mathrm{~g} \mathrm{~cm}^{-2} \mathrm{kyr}^{-1}$, respectively, and show distinct differences between glacial and interglacial periods (Table 3, Fig. 7). On the western margin, the LSR and $\mathrm{AR}_{\text {bulk }}$ values are generally somewhat higher during glacials (MIS 6 and MIS 2) than during interglacials (MIS 5 and MIS 1). The LSR during MIS 4 and MIS 3 are comparable to interglacial values. On the eastern margin, variations in LSR and $\mathrm{AR}_{\text {bulk }}$ values apparently do not reflect glacial or interglacial trends. In contrast to the western margin, LSR during MIS 2 are very low $(1.6 \mathrm{~cm} / \mathrm{kyr})$. Higher rates were attained in early MIS 3 (55-37 kyr). Enhanced AR bulk values also occur during MIS $1\left(7.9 \mathrm{~g} \mathrm{~cm}^{-2} \mathrm{kyr}^{-1}\right)$. However, these increased values are widely consistent with the spatial pattern along the Eurasian margin (cf. Knies, 1999), which might be explained by sediment redistribution processes (cf. Elverhøi et al., 1989; Pfirman et al., 1994).

\subsection{IRD}

We use the input of coarse lithogenic IRD ( $>2$ $\mathrm{mm})$ as a monitor of glacier fluctuations of the Barents /Kara Sea ice-sheets (e.g., Hebbeln, 1992; Baumann et al., 1995; Mangerud et al., 1998). Peak values of the coarse fraction $(>63 \mu \mathrm{m})$ without biogenic carbonate are also in good correlation with IRD records and can be used as tracer of significant terrigenous input by ice-sheets (e.g., Hebbeln and Wefer, 1997).

Maximum IRD input along the northern Barents Sea occurred during major deglacial phases, MIS event 6.3, Terminations I and II, and at the MIS transition 4/3 (Fig. 4). Abundant peaks of IRD on the northern Kara Sea margin are found in mid MIS 6, Termination II, late MIS 5, and early and middle MIS 3 (Fig. 4). Whereas several smaller IRD pulses can be recognized along the northern Barents Sea during glacial and interglacial periods, IRD sedimentation is almost absent along the northern Kara Sea (Fig. 4).

\subsection{Carbonate}

In general, carbonate contents in the study area mostly parallel the abundance curves of planktonic and benthic foraminifera (cf. Andersen et al., 1996; Hebbeln and Wefer, 1997). Dolomitic carbonate is only of secondary importance (cf. Knies et al., 1999). In all cores, the highest biogenic carbonate contents are found in glacial sediments. Along the northern

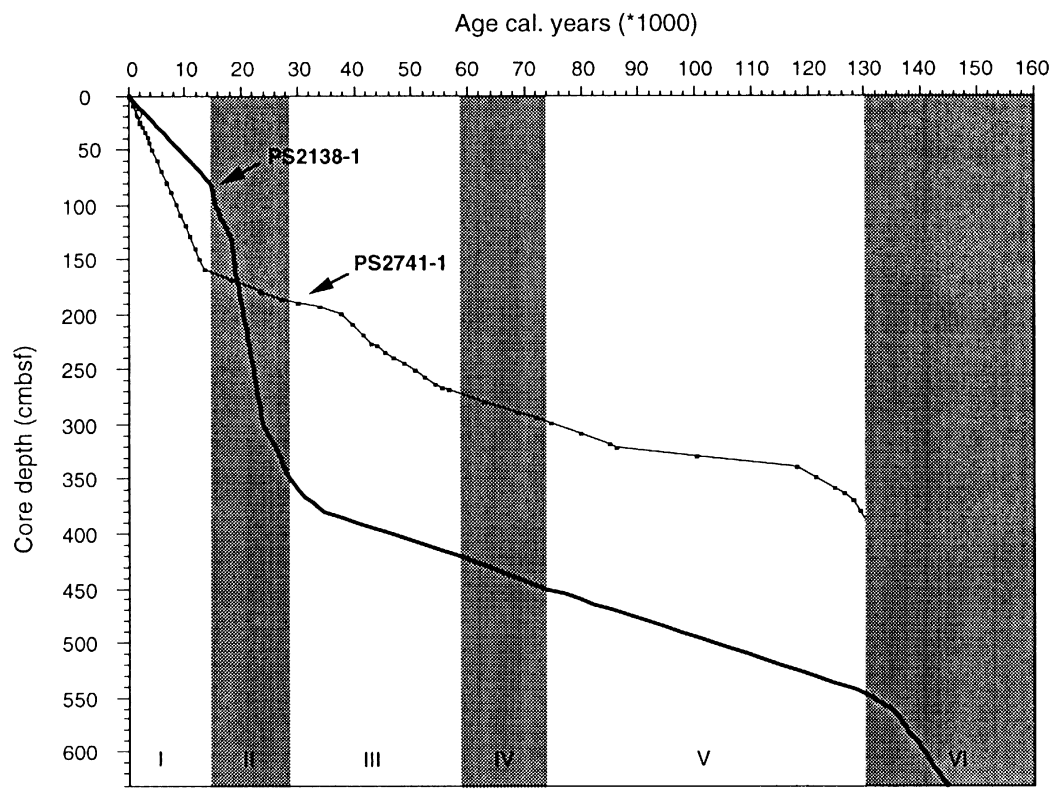

Fig. 4. Age-vs.-depth diagram for PS2138-1 and PS2741-1. 
Barents Sea margin, peak values (up to $15 \%$ ) occur during MIS 6, late MIS 3 and MIS 2 (Fig. 4). Highest amounts of biogenic carbonate (up to 4\%) are also observed during late MIS 3 and MIS 2 on the northern Kara Sea margin (Fig. 4). In contrast, significant carbonate contents during MIS 6 and early MIS 3 are of detrital origin. During interglacials, the carbonate content varies between $0 \%$ and $4 \%$ and is mostly composed of dolomite. Only surface sediments contain minor amounts of biogenic carbonate. Pervasive evidence of dissolution during interglacials is seen in the preservation of calcareous microfossils in the coarse fraction.

\section{4. $T O C$}

Along the Eurasian continental margin, the TOC content varies between $0.4 \%$ and $2.5 \%$ (Fig. 4). These values are significantly higher than in openocean marine sediments, i.e., in the central North Atlantic (Romankevich, 1984). Peak TOC values occur in laminated and IRD-enriched sequences during glacial and deglacial periods, and during the Upper Holocene, respectively (Fig. 4). However, we caution the reader that no adjustment has been made for the progressive increase in the proportion of easily metabolize organic matter in the Holocene section of each core. Until more geochemistry has been done, we interpreted the composition of the TOC only for two sources of organic matter input, i.e., marine (MOM) and terrestrial organic matter (TOM). The input of freshwater organic matter has not been investigated yet.

\subsection{Type of organic matter (terrestrial vs. marine)}

A first comprehensive overview of the dominating organic fraction in the sediments is given by bulk organic analysis, like Rock Eval pyrolysis and stable isotope analysis (e.g., Jasper and Gagosian, 1989; Stein, 1991; Naidu et al., 1993). In immature TOCrich sediments $(>0.5 \%), \mathrm{HI}<100 \mathrm{mg} \mathrm{HC} / \mathrm{g}$ TOC are typical for TOM (kerogen types III + IV) (Tissot and Welte, 1984). HI values of $<100 \mathrm{mg} \mathrm{HC} / \mathrm{g}$ TOC occur throughout the entire records, reflecting the predominance of TOM input over the last 150 kyr (Fig. 4). Along the northern Barents Sea margin, light $\delta^{13} \mathrm{C}$ values $(-27$ to $-24 \%$ ) are characteristic for glacial and deglacial periods and indicate a predominance of TOM-input as well (Fig. 4). Heavier values (up to $-22.5 \%$ ) between MIS 5 and MIS 3, and during the Holocene indicate slightly higher proportions of MOM (Fig. 4). On the northern Kara Sea margin, lighter $\delta^{13} \mathrm{C}$ values (up to $-24.2 \%$ ) occur during MIS 6 and early MIS 3 (Fig. 4). Mean $\delta^{13} \mathrm{C}$ values of $-23 \%$ o between MIS 6 and MIS 1 may indicate similar proportions of MOM, as found along the northern Barents Sea margin, although neither results from kerogen microscopy (B. Boucsein, personal communication) nor extremely low $\mathrm{HI}$ values $(<50 \mathrm{mg} \mathrm{HC} / \mathrm{g} \mathrm{TOC})$, and $\mathrm{C}_{17}+\mathrm{C}_{19} n$-alkane concentrations $(<0.1 \mu \mathrm{g} / \mathrm{g}$ Sed. $)$ can confirm this $\delta^{13} \mathrm{C}$ trend (Fig. 4). On the contrary, these proxies indicate a predominent terrigenous/reworked source of the organic matter. Coal fragments with $\delta^{13} \mathrm{C}$ values of up to $-23 \%$ o delivered by Siberian rivers onto the shallow Eurasian shelves and transported via sea-ice and/or icebergs to the northern Kara Sea margin can probably explain the heavier $\delta^{13} \mathrm{C}$ values in PS2741-1 (cf. Wagner, 1993).

Identification of contributions of MOM to the sediments are supported by short-chain $n$-alkanes $\left(\mathrm{C}_{17}+\mathrm{C}_{19}\right)$ (Blumer et al., 1971; Schubert and Stein, 1997) and chlorophyll-derived pigments (chlorins) (Harris et al., 1996; Rosell-Melé and Koc, 1997). Mean concentrations of $\mathrm{C}_{17}+\mathrm{C}_{19} n$-alkanes are significantly higher on the western $(0.47 \mu \mathrm{g} / \mathrm{g}$ Sed. $)$ than on the eastern margin $(0.1 \mu \mathrm{g} / \mathrm{g} \mathrm{Sed}$.) (Fig. 4).

Fig. 5. Results of analyses of (a) PS2138-1 and (b) PS2741-1 vs. depth (cmbsf): For all cores, lithological description, contents of carbonate, organic carbon (all in wt.\%), the $\mathrm{HI}$ (mg HC/g TOC), $\delta^{13} \mathrm{C} \mathrm{C}_{\text {org }}$ values (\%o), and specific biomarkers, like long-and short-chain $n$-alkanes (all in $\mu \mathrm{g} / \mathrm{g}$ Sed.), pigment absorbance values (at $665 \mathrm{~nm}$ ), and IRD (No. $>2 \mathrm{~mm} / 10 \mathrm{ccm}$ ) records are shown. Detrital amounts of carbonate in core PS2741-1 are assumed by visual inspection of the coarse fraction $(>63 \mu \mathrm{m})$. The highest CPI values $(>4)$ are marked in specific sediment sequences. Generally, the CPI values vary between 1 and 2 during the whole time span. MIS stages including Terminations I (TI) and II (TII) are displayed on the right hand side. 
PS2138-1 SL

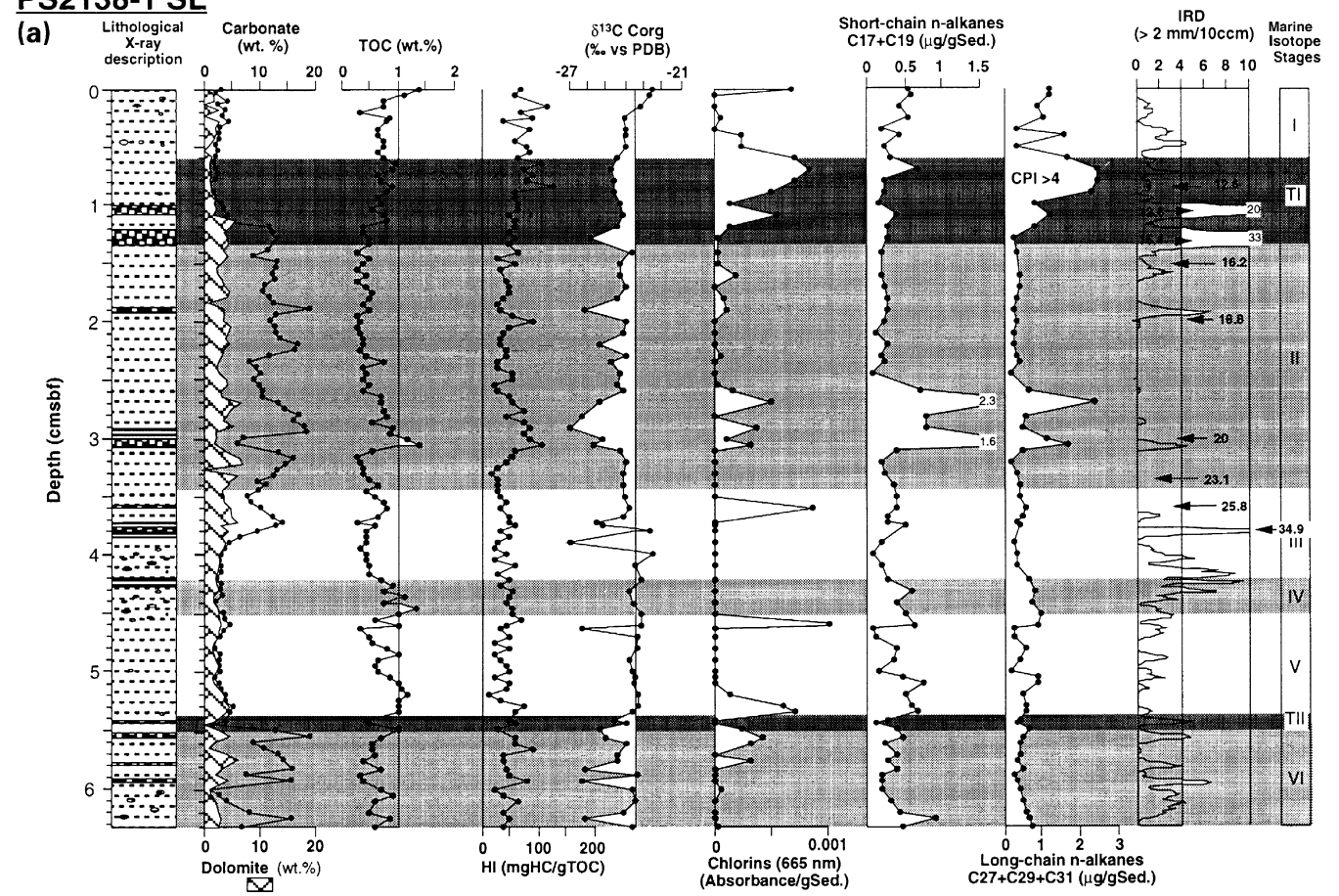

\section{PS2741-1 KAL}

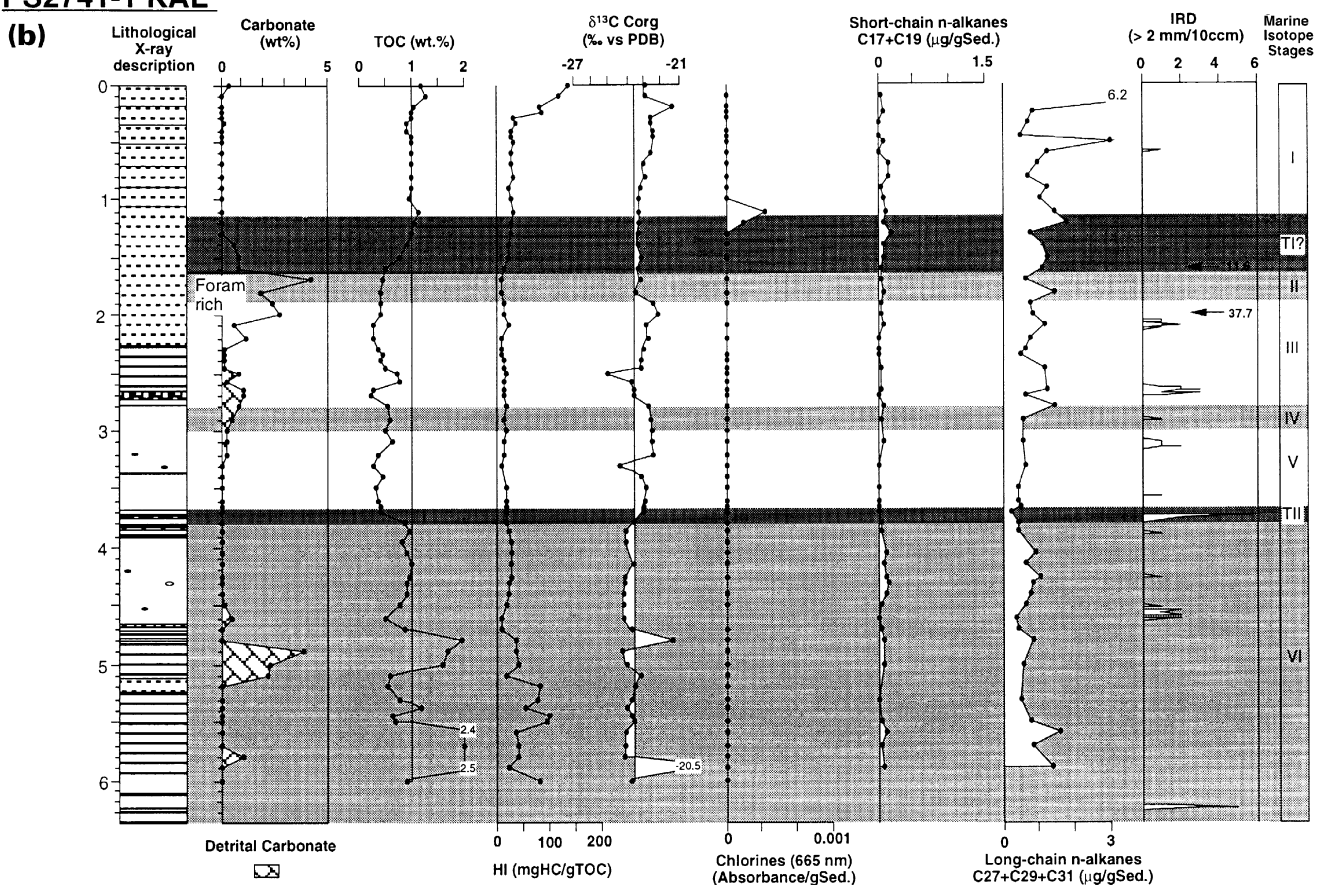

X-Radiograph-description

Bioturbated mud/enriched in dropstones
$\begin{aligned} & \text { Bioturbated mud with layers of sand and gravel slightly } \\ & \text { laminated and thin sandy layers (contour currents?) }\end{aligned}$ 
Distinct maxima in chlorine absorbance along the northern Barents Sea margin occur during deglacial and interglacial periods. Distinctly higher values occur during substages 6.3, 5.5, 5.1, late MIS 3, Termination I and Late Holocene (Fig. 4). Distinctly lower values occur on the northern Kara Sea margin. One single peak in chlorine absorbance is observed during Early Holocene (Fig. 4).

The long-chain $n$-alkanes $\left(\mathrm{C}_{27}, \mathrm{C}_{29}\right.$ and $\left.\mathrm{C}_{31}\right)$ were used to trace the continental contribution to the organic matter (Eglington and Hamilton, 1967). Mean values of long-chain $n$-alkanes are higher on the eastern $(1.0 \mu \mathrm{g} / \mathrm{g}$ Sed.) than on the western margin $(0.68 \mu \mathrm{g} / \mathrm{g}$ Sed.). However, the highest contents are found during Termination I along the Barents Sea margin (up to $2.5 \mu \mathrm{g} / \mathrm{g}$ Sed.) and during the Holocene on the northern Kara Sea margin (Fig. 4). The relation of odd-to-even carbon atom numbers of $n$-alkanes between $\mathrm{C}_{21}$ and $\mathrm{C}_{32}$, defined as carbon preference index (CPI), is a measure of the maturity of the organic matter (Bray and Evans, 1961). Along the Eurasian continental margin, CPI values between 1 and 2 generally indicate that fossil TOM-input predominates throughout the investigated time peri-

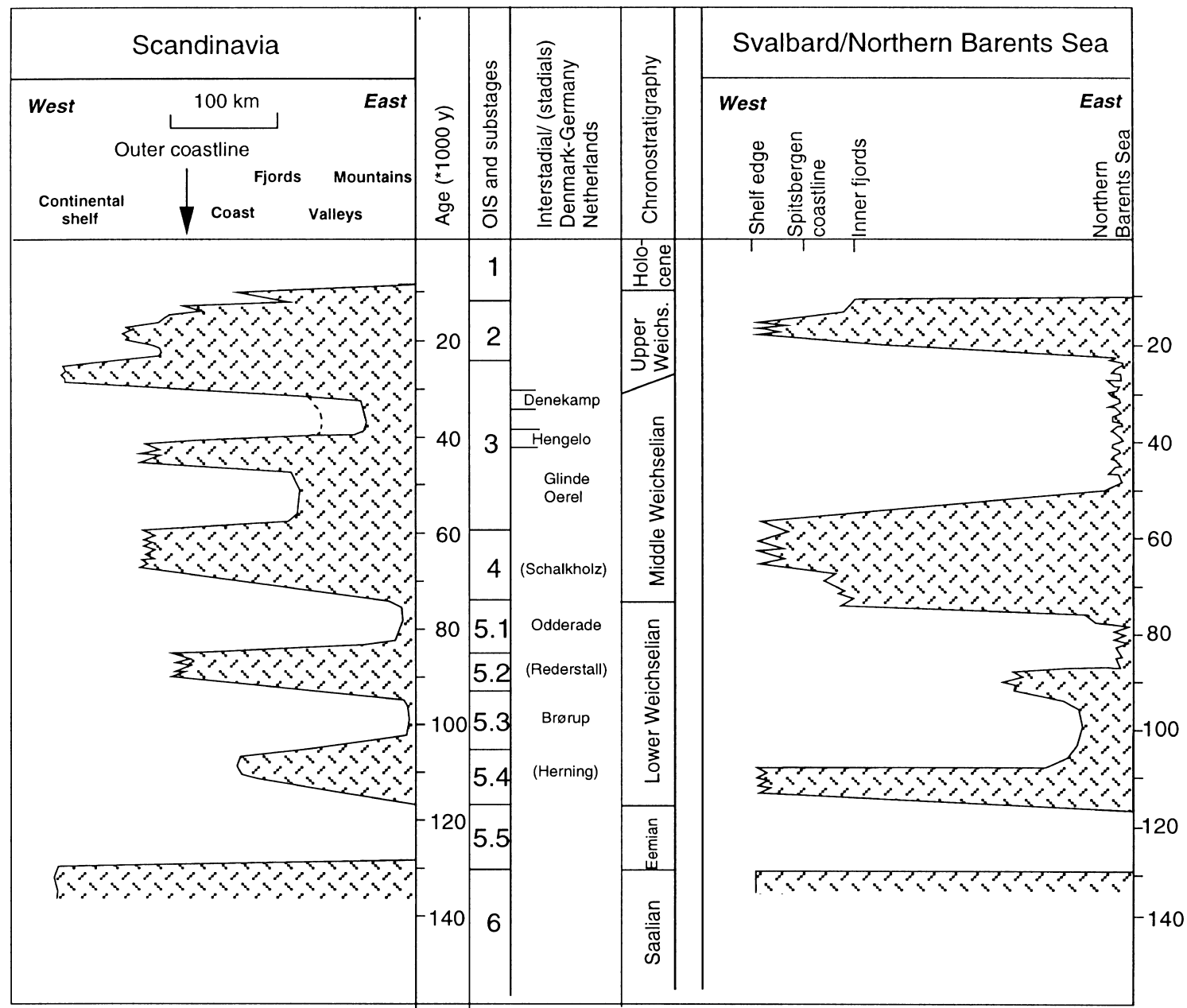

Fig. 6. The glaciation fluctuations of the SIS and SBIS during the last glacial/interglacial cycle (cf. Mangerud et al., 1996, 1998). 
ods. Higher values (CPI > 3) found for Termination I on the western margin imply higher input of rather fresh TOM (Hollerbach, 1985).

\section{Discussion}

\subsection{Glaciation history and correlation to the terres- trial record}

The glaciation curves of the Scandinavian (SIS) and the Svalbard/Barents Sea ice-sheets (SBIS) during the Weichselian as interpreted from the onshore sections correlate well with the IRD input in the deep ocean along the western Norwegian and Svalbard margins (e.g., Hebbeln, 1992; Mangerud and Svendsen, 1992; Baumann et al., 1995; Mangerud et al., 1998 for a recent discussion). Maximum IRD input occurred particularly during deglaciation phases of the most extended ice-sheets when a broad ice front reached the continental shelf edge, disintegrated, and subsequently melted (i.e., Mangerud et al., 1998). Based on those results, major ice front fluctuations of SIS and SBIS during the last glacial/interglacial cycle have been reconstructed (cf. Fig. 5).

Larsen and Mangerud (1990) concluded that the fjord and coastal areas in Scandinavia were glaciated and deglaciated several times. During the Weichselian, the glacier front passed the coastline at least four times. This highly variable waxing and waning of ice is closely related to the near $23 \mathrm{kyr}$ precession cycles of the Earth's orbit (Ruddiman and McIntyre, 1981; Mangerud et al., 1996).

The glaciation curve of the SBIS shows less extensive glacier advances than that of the SIS. Significant ice advances to the western Svalbard margin probably occurred during MIS 6, substage 5.4, MIS 4 and MIS 2 (cf. Mangerud et al., 1998). Landvik et al. (1992) concluded that the glaciers

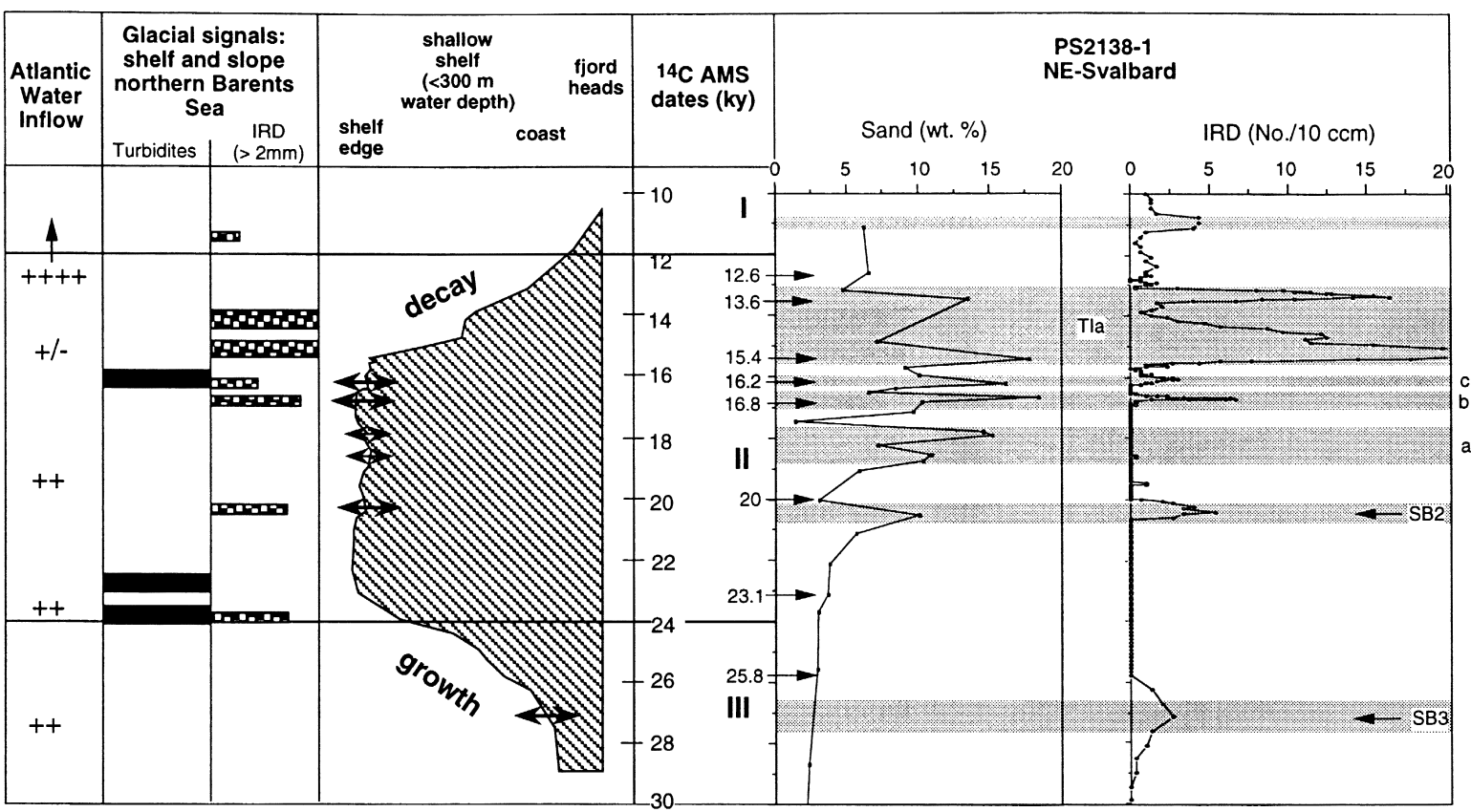

Fig. 7. The left panel shows the extension of the ice-sheet on the northern Barents Sea margin during the last glacial cycle (in ${ }^{14} \mathrm{C}$ ages) with respect to Atlantic water inflow, turbidite occurrences, and IRD peak values. The right panel shows the IRD record and the coarse fraction without biogenic carbonate of PS2138-1 corresponding to the model. The turbidites along the northern Barents Sea margin are described in detail by Kleiber et al. (in preparation). Measured AMS ${ }^{14} \mathrm{C}$ datings are indicated. SB2 and SB3 (SB: Svalbard/Barents Sea) mark pronounced IRD deposition events contemporary to the North Atlantic Heinrich events H2 and H3. For explanation of IRD events (a)-(c) see text. TIa: Termination Ia. 
probably survived in the northern parts of the Barents Sea during the entire MIS 5. Based on IRD records in the Fram Strait and the western Svalbard margin, ice advance to the shelf edge could be confirmed during substage 5.4 (Mangerud et al., 1998), MIS 4 and MIS 2 (Hebbeln, 1992). Lloyd et al. (1996) suggest a major advance during substage 5.2 , which is only partly consistent with the terrestrial records (Mangerud et al., 1998).

Detailed investigations of SBIS extension during the Late Weichselian are summarized by Elverhøi et al. (1995) and Andersen et al. (1996). They concluded that the first significant ice advance beyond the present coastline occurred $\sim 22{ }^{14} \mathrm{C}$ kyr and that ice advanced to the shelf edge at $\sim 18{ }^{14} \mathrm{C}$ kyr. Disintegration of the SBIS began at $14.8{ }^{14} \mathrm{C} \mathrm{kyr}$, and a second stage occurred between 13 and $12{ }^{14} \mathrm{C}$ kyr. According to Mangerud and Svendsen (1992), the major glacier advances of SBIS apparently follow the 41-kyr cycles of the tilt of the Earth's rotation axis, which at this latitude is more important for the summer insolation than the $23-\mathrm{kyr}$ precession cycles.

The glaciation curves of the central Barents / Kara Sea ice-sheets during the Late Weichselian are still under discussion (e.g., Grosswald, 1993; Pavlidis et al., 1997; Velitchko et al., 1997a,b). Recently, Mangerud et al. (1999) concluded that the ice extent at the LGM on the Eurasian shelves in the east of Europe and Siberia was rather limited in size, compared to the SIS and the SBIS. Furthermore, they postulated a much more extensive ice-sheet cover during Early and Middle Weichselian glaciation, which is in good agreement with marine studies by Weiel (1997) and Kleiber and Niessen (1999).

\subsection{The Late Weichselian glaciation along the northern Barents Sea margin}

The glaciation history of the SBIS along the northern Barents Sea during the last glacial cycle can be deduced from the sedimentary records of core PS2138-1 (Fig. 6). Due to high sedimentation rates (cf. Table 3), oscillations of the northern SBIS during the last glacial cycle are preserved on a highly resolved time scale.

During the early and middle stages of ice growth, moisture supplied by intruding Atlantic water in combination with lower summer insolation that prohibited iceberg calving, enforced the final build-up of the SBIS (cf. Fig. 6) (i.e., Hebbeln et al., 1994; Dokken and Hald, 1996; Knies et al., 1999). First initial instability of the ice-sheet during build-up is recorded by a distinct IRD peak $\sim 27{ }^{14} \mathrm{C}$ kyr (SB3) (Fig. 6), which corresponds to the contemporaneous Heinrich event 3 in the North Atlantic (Bond et al., 1992). In accordance with Laberg and Vorren (1995), ice advance onto the shelf and to the shelf edge culminated in deposition of debris flows at the continental margin $\sim 23{ }^{14} \mathrm{C}$ kyr ago (cf. Fig. 6) (i.e., Kleiber et al., in preparation). After reaching the maximum extension at $\sim 20{ }^{14} \mathrm{C}$ kyr, huge amounts of kaolinite-rich sediments (up to 40\%) (Fig. 9) from the northern Barents Sea shelf (cf. Birkenmajer, 1989; Stein et al., 1994b) were released in the basal parts of the ice and triggered extremely high bulk

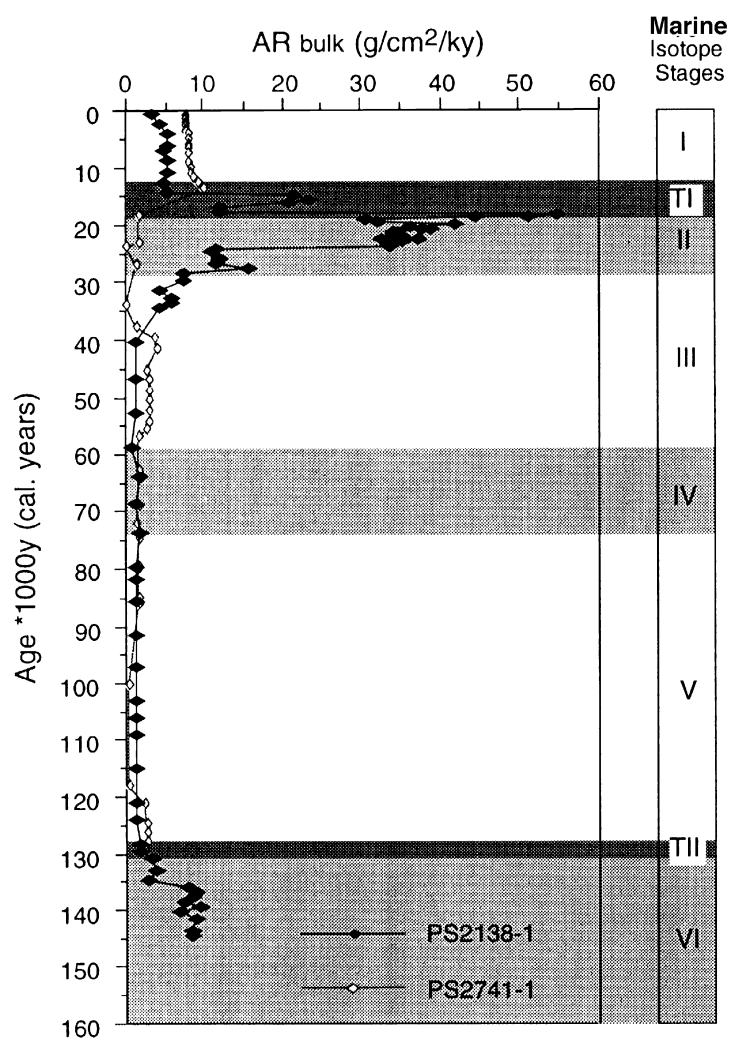

Fig. 8. Bulk accumulation rates $\left(\mathrm{AR}_{\text {bulk }}\right.$ in $\left.\mathrm{g} \mathrm{cm}^{-2} \mathrm{kyr}^{-1}\right)$ of PS2138-1 and PS2741-1 vs. calendar ages. MIS are displayed on the right hand side. 


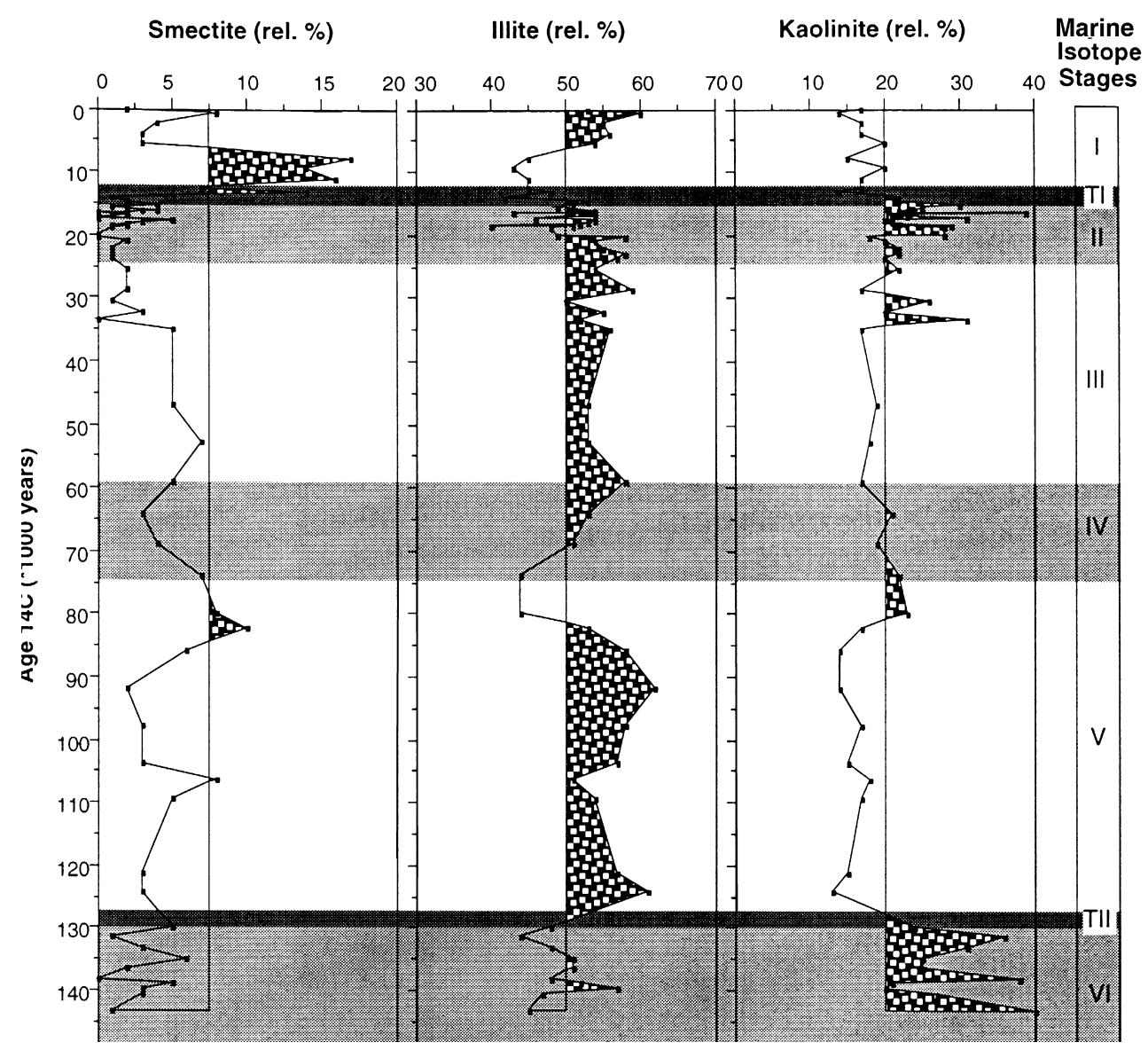

Fig. 9. Clay mineralogy distribution (rel.\%) in PS2138-1 vs. AMS ${ }^{14} \mathrm{C}$ ages.

accumulation rates (up to $50 \mathrm{~g} \mathrm{~cm}^{-2} \mathrm{kyr}^{-1}$ ) (Fig. 7). In contact with the sea, the ice first broke up at $\sim 20$ ${ }^{14} \mathrm{C}$ kyr (SB2), as indicated by major IRD units overlaid by laminated sediments and distinct meltwater supply $\left(\delta^{18} \mathrm{O}: 4 \%\right.$; $\delta^{13} \mathrm{C}:-0.5 \%$; cf. Figs. 2 and $8)$; this corresponds to the contemporaneous Heinrich event 2 in the North Atlantic (Bond et al., 1992). At least, three IRD pulses (a-c, cf. Fig. 6) reflect the waxing and waning of the SBIS on the outer shelf between 19 and $16.2{ }^{14} \mathrm{C}$ kyr. We postulate that the ice-sheet collapsed several times due to repeated readvance to the shelf edge with subsequently higher calving rates. These events are in good correlation with IRD pulses recorded in the northern North Atlantic (Bond and Lotti, 1995; Fronval et al., 1995; Stoner et al., 1996) and may reflect synchronous fluctuations of the northern Hemisphere ice-sheets on a millennial time scale (e.g., Broecker, 1994; Bond and Lotti, 1995). However, McCabe and Clark (1998) suggest that a sudden collapse of the most extended SBIS could also have occurred in response to a rise in sea level caused by a Laurentide ice-sheet surge during each Heinrich event (cf., MacAyeal, 1993).

Rapid ice disintegrations along the northern Barents Sea continental margin started $\sim 15.4{ }^{14} \mathrm{C}$ kyr (Fig. 6), triggered by increasing summer insolation and global rise in sea level (Ruddiman and McIntyre, 1981; Fairbanks, 1989). Contemporary influx of meltwater and poorly ventilated low-saline surface water masses are indicated by prominent $\delta^{13} \mathrm{C}$ minima and low $\delta^{18} \mathrm{O}$ excursions (cf. Fig. 2), and can be 
traced to the central Arctic Ocean and the Fram Strait (e.g., Jones and Keigwin, 1988; Stein et al., 1994a,c; Nørgaard-Pedersen et al., 1998). Armadas of icebergs and extensive meltwater lids prohibited further decay of the ice-sheets because of a significant cooling of the ocean triggered by positive icealbedo feedback mechanisms and sea-ice formation (e.g., Ruddiman and McIntyre, 1981). After a short delay, a second major IRD pulse $\sim 13.6{ }^{14} \mathrm{C} \mathrm{kyr}$ reflects increased iceberg calving due to further icesheet decay by still rising summer insolation and sea level. Moderate IRD input during the Holocene can probably be explained by surging of tidewater glaciers of Nordaustlandet or Franz Josef Land and/or by short-term glacial readvances to the outer coastline (cf. Pfirman and Solheim, 1989). A distinct IRD peak $\sim 11{ }^{14} \mathrm{C}$ kyr ago may indicate an extended ice-sheet along the northern Barents Sea continental margin during the Younger Dryas. However, with the low stratigraphic resolution of the Holocene record this assumption remains speculative.

\subsection{Upper Saalian (MIS 6) to Late Weichselian (MIS 2) glaciation}

A scenario comparable to that described above is postulated for MIS 6 (Knies et al., 1999). A greatly extended ice-sheet, probably reaching the shelf edge, is documented by high $\mathrm{AR}_{\text {bulk }}$ values $\left(15 \mathrm{~g} \mathrm{~cm}^{-2}\right.$ $\left.\mathrm{kyr}^{-1}\right), \delta^{13} \mathrm{C}$ values between $-25 \%$ and $-27 \%$ o (Figs. 4 and 7), and high kaolinite contents similar to those of the LGM (Fig. 9). Mesozoic bedrocks of the northern Barents Sea were eroded by glacial activity during MIS 6 and delivered to the slope by suspension plumes when the maximum ice-sheet extension was reached. A first significant deglacial event is recorded during MIS event 6.3 (Fig. 10) and corresponds to a contemporaneous event on the western Scandinavian margin (cf. Wagner and Henrich, 1994;

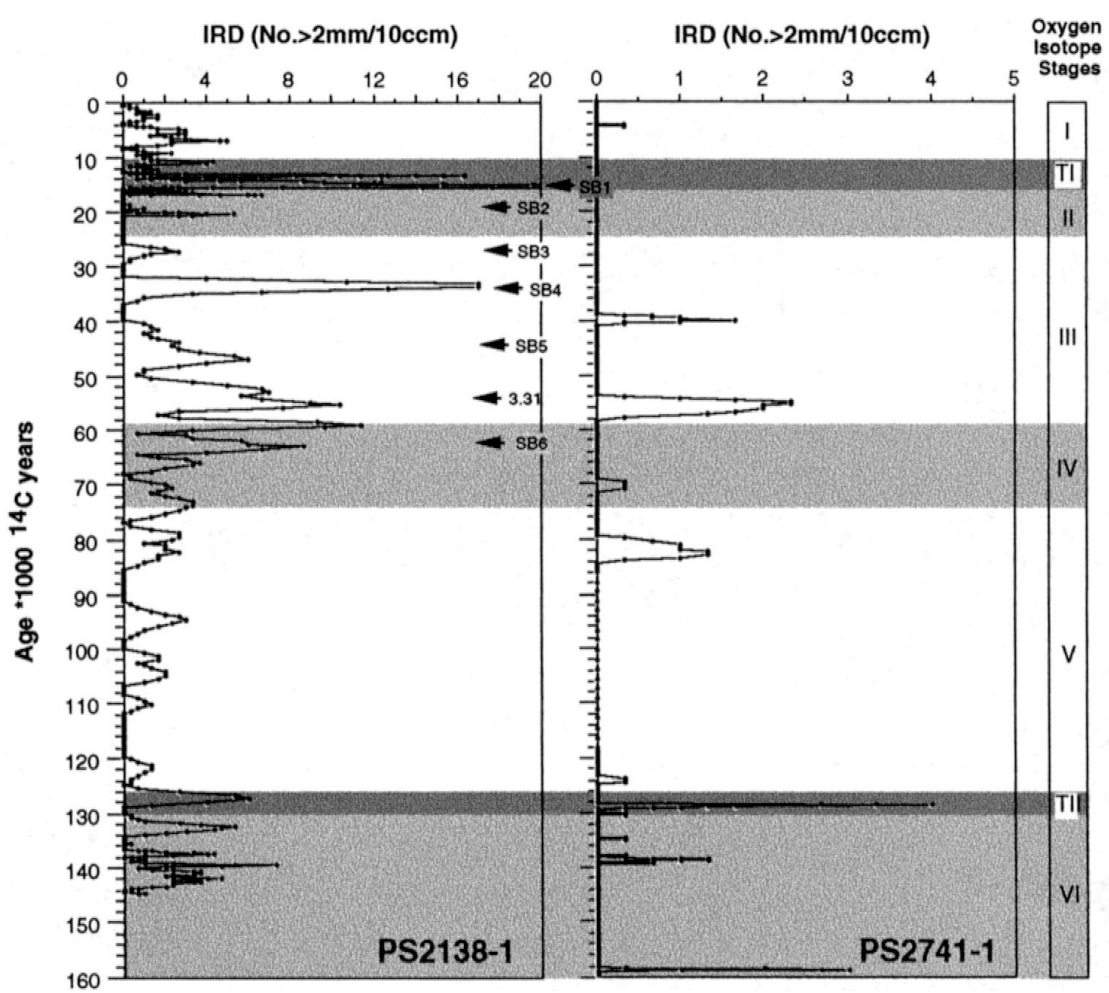

Fig. 10. Comparison of IRD records from the western (PS2138-1) and eastern (PS2741-1) Eurasian continental margin vs. ${ }^{14} \mathrm{C}$ ages. AMS

${ }^{14} \mathrm{C}$ ages are used in order to compare results from the western Svalbard margin by Elverhøi et al. (1995), Andersen et al. (1996), and Dokken and Hald (1996). SB1-SB6 mark pronounced IRD deposition events contemporary to the North Atlantic Heinrich event H1-H6. MIS event 3.31 is indicated. MIS stages are shown on the right hand side. Note the stratigraphic uncertainties of PS2741-1 during MIS 6. 
Baumann et al., 1995). Although only a few stratigraphic fixpoints exist, we suggest that further IRD pulses between MIS event 6.3 and Termination II may reflect, similar to IRD events of the LGM, higher calving rates and deliverance of IRD after repeated readvances of the marine-based ice-sheet to the shelf edge (cf. Fig. 10). A first step in the disintegration of the ice-sheet is recognized at $\sim 134$ kyr. This age correlates well with enhanced IRD input in the NGS and is associated with melting of the Late Saalian (MIS 6) ice-sheets (Fronval and Jansen, 1997). A delay of disintegration comparable to that found during Termination I can be observed. A second, distinct IRD pulse and distinct meltwater influx occurs between 128 and 126 kyr (Termination II) (Fig. 10).

During mid MIS 5, moderate input of IRD recorded along the northern Barents Sea margin and low $\mathrm{AR}_{\text {bulk }}$ values suggest minor glacial activity onshore in contrast to the western Svalbard margin (Mangerud and Svendsen, 1992). High illite contents, which are related to the Svalbard Archipelago as the most probable source (Stein et al., 1994b) document the retreat of the SBIS onshore during MIS 5 (Fig. 9). Landvik et al. (1992) suggested that the ice margin was still at the outer coastline between substages 5.4 and 5.2. We propose that smaller glacier advances during colder periods and episodic surging are reflected by moderate IRD input, probably during substage 5.4 , and at the boundaries 5.4/5.3 and 5.2/5.1 (Fig. 10). Nevertheless, minimal $\mathrm{AR}_{\text {bulk }}$ values and high illite contents indicate that the ice-sheet along the northern Barents Sea did not reach the outer shelf during MIS 5 .

During MIS 4, the SBIS expanded to the western Svalbard margin, probably to the shelf edge (Mangerud and Svendsen, 1992). There are no indications for a greatly extended ice-sheet at the northern Barents Sea margin (Knies et al., 1999). Even though significant IRD pulses at the end of MIS 4 (Fig. 10) hint to glacial activity due to ice growth onto the shelf, the lower $\mathrm{AR}_{\text {bulk }}$ values of MIS 4 compared to MIS 6 and MIS 2 (Fig. 7) clearly indicate a lower terrigenous supply and thus a more restricted ice-sheet extension and probably a closely packed sea-ice cover. However, slightly enhanced kaolinite contents indicate a more extended ice-sheet, probably to the outer coastline, than during MIS 5
(Fig. 9). A major deglacial event between 57 and 52 kyr corresponding to MIS event 3.31 is indicated by very intensive IRD input (Fig. 10) and can be traced far into the central Arctic Ocean. Darby et al. (1997) and Nørgaard-Pedersen et al. (1998) correlated this deglacial event in Arctic Ocean sediment cores with ice-sheet degradation and meltwater discharge subsequent to the Middle Weichselian glaciation, occurring around $60 \mathrm{kyr}$ on the Eurasian shelves (Mangerud et al., 1999).

Generally, moderate $\mathrm{AR}_{\text {bulk }}$ values and high illite contents along the northern Barents Sea margin during mid and late MIS 3 (Figs. 7 and 9) confirm that the Middle Weichselian glaciation (MIS 4) was succeeded by a long ice-sheet-free period until the readvance started during the Late Weichselian (Mangerud et al., 1996). Hebbeln and Wefer (1997) suggest a closely packed sea-ice cover with a subsurface advection of Atlantic water for this time interval in the Fram Strait. However, between the major deglaciation event 3.31 and the onset of the last glaciation, three major IRD pulses (SB5-SB3), contemporaneous with the Heinrich events 5, 4 and 3 in the North Atlantic (Bond et al., 1992) are recorded northeast of Svalbard (Fig. 10). At least one (SB4) correlates with higher contents of kaolinite (up to $30 \%$ ) and could indicate an advanced SBIS to the shallow shelf in mid MIS 3. In fact, the IRD record during MIS 3 displays a much lower frequency of ice-sheet oscillations than suggested for the western margins of SIS and SBIS (cf. Baumann et al., 1995; Fronval et al., 1995; Andersen et al., 1996). That means that comparable to the LGM, major Laurentide ice-sheet surgings resulting in IRD-enriched Heinrich layers in the North Atlantic could have triggered the collapse of the ice margin in the north of Svalbard in response to a short-term rise in sea level (McCabe and Clark, 1998). However, periodically surging ice margins like those common on Svalbard and Franz Josef Land today (Liestøl, 1969) could also have delivered huge quantities of extraordinary sediment-laden icebergs concurrent to the Heinrich events in the North Atlantic. This could explain similar to the LGM a near-synchronous response of the circum-Atlantic ice-sheets triggered by external climate forcing beyond the North Atlantic as suggested by Bond and Lotti (1995) and Fronval et al. (1995). 
6.4. Glaciation history of the Severnaya Semlya icesheet (SSIS)

The variability of the SSIS oscillations seems to be much lower during the last $150 \mathrm{kyr}$ compared to the SBIS (Fig. 10). Short-term climatic changes presumably have lower influence on glacial activity in this low-precipitation area than on the western margin. Indications for a broad ice front in an advanced position on the outer shelf, probably along the shelf edge, are recorded by two distinct IRD peak values during mid MIS 6 (probably MIS event 6.3) and Termination II in PS2741-1 (Fig. 10). According to
Mangerud et al. (1998), we postulate that these IRD peak values monitor glacial maxima and/or deglaciation phases when huge amounts of icebergs were released. Fine laminated sequences and high contents of smectite and kaolinite preceding the IRD pulse at mid MIS 6 in PS2741-1 (Fig. 11) may indicate that sedimentation on the lower slope of Severnaya Semlya has not been directly affected by the SSIS advance onto the shelf. Indeed, the predominance of smectite and kaolinite indicate bottom transport of suspension-loaded plumes delivered by submarine meltwater discharge from the advanced Kara Sea ice-sheet, probably from Franz Josef Land,
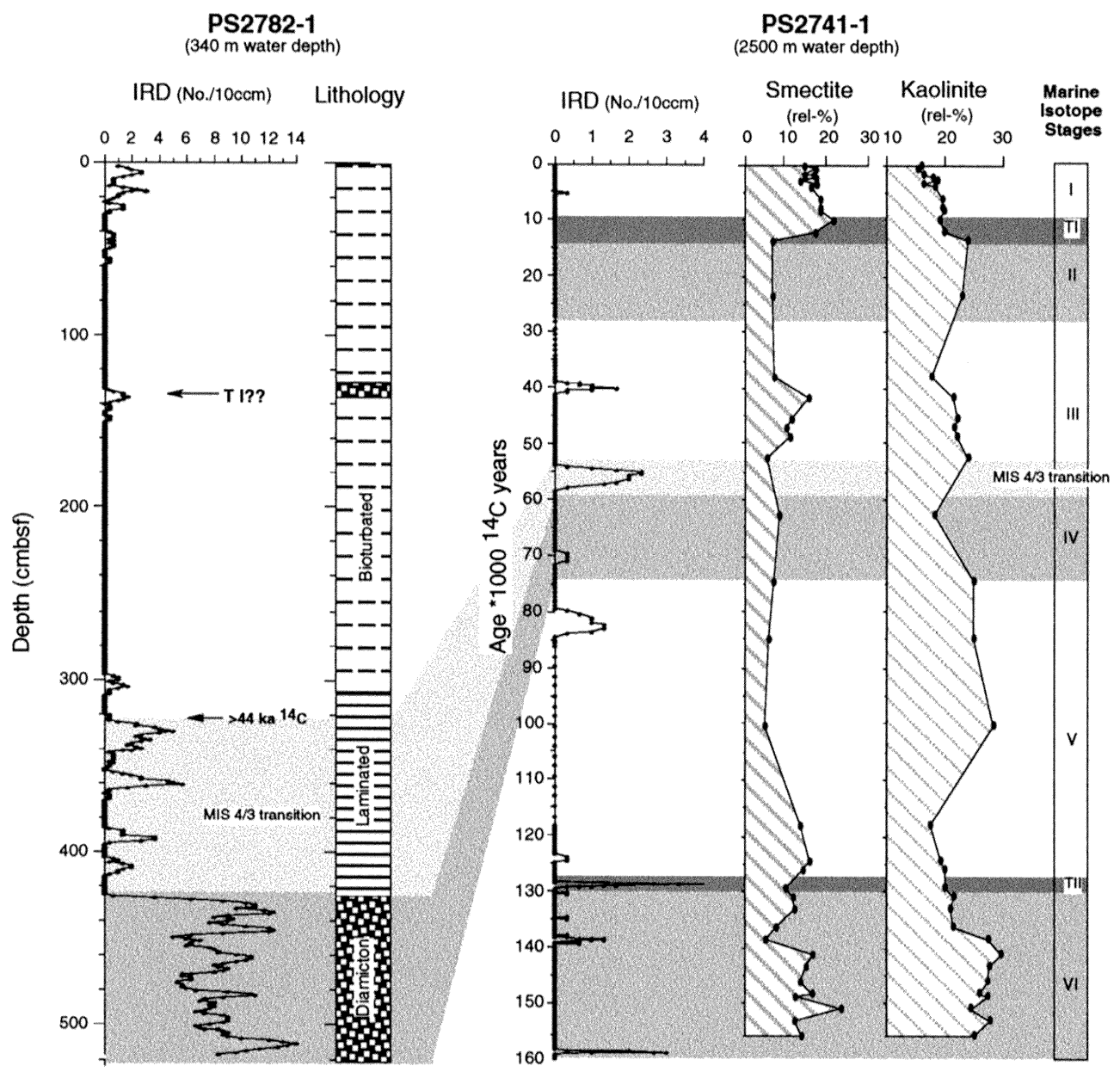

Fig. 11. Correlation of bulk analyses in core PS2782-1 (IRD, lithology) vs. depth with IRD, and carbonate records, as well as smectite and kaolinite percentages of core PS2741-1 vs. ${ }^{14} \mathrm{C}$ ages. Single AMS ${ }^{14} \mathrm{C}$ dating in $321-\mathrm{cm}$ core depth of PS2782-1 is indicated. Lithological description is shown in Fig. 5. 
the St. Anna Trough and/or the Voronin Trough areas (cf. Vogt, 1997). The second major IRD input during Termination II might indicate the final retreat of the SSIS to the inner shelf.

During late MIS 5, a distinct IRD peak, probably at the MIS substage boundary 5.2/5.1 might reflect a readvance of the SSIS to the outer shelf (cf. Fig. 10), which can be correlated to the maximum icesheet extent in the Kara Sea during the Early Weichselian suggested by Mangerud et al. (1999) and Svendsen et al. (1999).

During MIS 4 indications for an advanced icesheet onto the outer shelf of Severnaya Semlya occur by a distinct IRD peak overlaid by laminated sediments during MIS 4/3 transition in PS2741-1 (cf. Figs. 4 and 10). This pronounced event may reflect a huge meltwater discharge subsequent to the large glaciation in the Kara Sea during the Middle Weichselian (MIS 4) proposed by Svendsen et al. (1999). Possible evidences for a grounded ice-sheet along the northern margin of Severnaya Semlya during MIS 4 are probably reflected in the shallow core PS2782-1 (Fig. 11). A coarse-grained diamicton at the core base of PS2782-1, which is in accordance to Lubinski et al. (1996) and Polyak et al. (1997) interpreted as till or ice-marginal debris flow, has an age older than the Late Weichselian (Fig. 11). This is indicated by an infinite ${ }^{14} \mathrm{C}$ age $(>44 \mathrm{kyr})$ in 321 $\mathrm{cm}$ core depth. In addition, the occurrences of welldefined moraine ridges at $385 \mathrm{~m}$ water depth nearby PS2782-1 (cf. Niessen et al., 1997; Weiel, 1997) recommend a similar age than the diamicton. The diamicton is overlaid by laminated sediments and several IRD pulses, which point to a distinct deglaciation phase (cf. Polyak et al., 1997) (Fig. 11). Even though an Early Weichselian or Saalian age for the diamicton and the moraines cannot be ruled out, we suggest that the laminated and IRD-enriched sediment sequence above the diamicton correspond to the distinct deglacial MIS 4/3 transition in PS2741-1 and, therefore, propose a grounded icesheet during the Middle Weichselian (MIS 4) glaciation along the outer shelf of northern Severnaya Semlya in at least $340 \mathrm{~m}$ water depth.

For the Late (Valdai) Weichselian, we agree with Mangerud et al. (1999) and Svendsen et al. (1999), rejecting the so-called "Pan-Arctic Glaciation of the northern Hemisphere" model proposed by Denton and Hughes (1981) and Grosswald (1993) for the last glaciation. Very low $\mathrm{AR}_{\text {bulk }}$ values during MIS 2 (Fig. 7) and no IRD input during Termination $I$ in PS2741-1 (Fig. 10) may indicate instead a perennial sea-ice cover than an extended ice-sheet onto the shelf. Even in the shallow core PS2782-1, very low IRD values do not suggest an ice advance to the outer coastline (Fig. 11). However, for the Late Holocene, enhanced IRD input in PS2782-1 (Fig. 11) could indicate the Neoglaciation as observed in alpine glaciers, and in the North Atlantic and western Arctic Ocean marine records (Denton and Karlen, 1973; Keigwin and Jones, 1994, 1995; Darby et al., 1997).

Fig. 12 summarizes the glaciation curves for the northern Barents Sea/SSIS based on results of this study compared to the glacier fluctuations known from Scandinavia and western Svalbard. In more detail, (1) we modified the glaciation curve along the northern Barents Sea for the Late Weichselian and may have indications for a high-frequently collapsing ice-sheet on a millennial time scale similar to northern Hemisphere ice-sheets. (2) Short-term climatic changes as recorded in lower latitudes during the last glacial/interglacial cycle occur along the northern Barents Sea margin and may have influenced the interior Arctic Ocean environment as well (cf. Nørgaard-Pedersen et al., 1998). (3) Furthermore, we conclude that (a) oscillations of ice-sheets in low-precipitation areas are more limited and less frequent than in areas of continuous moisture supply like the SIS and SBIS and (b) major fluctuations of the Kara Sea ice-sheet during the last 150 kyr apparently followed the major interglacial/glacial MIS 5/4 and MIS 7/6 transitions as generally discussed by Ruddiman et al. (1980) and Velitchko et al. (1997a; b) rather than the precession (23 kyr) and the tilt (41 kyr) cyclicity of the Earth's orbit for the SIS and SBIS fluctuations, respectively (Mangerud et al., 1996).

\subsection{Depositional environment along the Eurasian continental margin}

Recently, Nørgaard-Pedersen et al. (1998) proposed a model for the Late Quaternary Arctic Ocean, describing surface ocean conditions and sedimentation patterns for the following three-end-member climate situations: (1) glacials with closely packed 

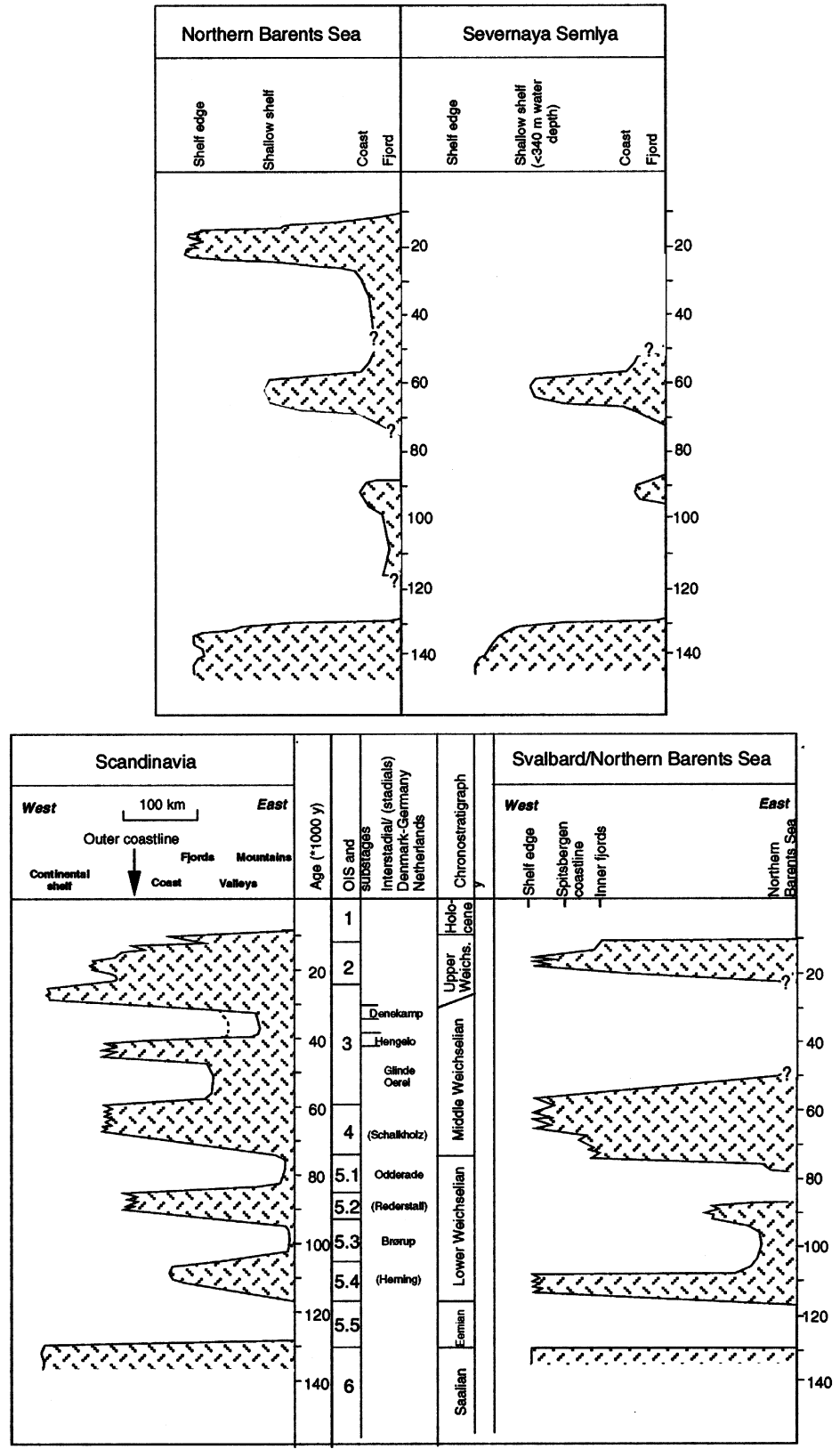

Fig. 12. Comparison of glacier fluctuations on the western margins (cf. Mangerud et al., 1996) with glaciation curves along the northern Barents Sea and Severnaya Semlya based on results from this study.

sea-ice cover, low $\mathrm{AR}_{\text {bulk }}$ values, and limited planktonic productivity, (2) deglacials with enhanced meltwater production and high $\mathrm{AR}_{\text {bulk }}$ values, and (3) interglacials with increased planktonic productivity and high ablation rates due to expanded open- water (lead) proportions. Extending this model, our refined multiproxy approach allowed a more detailed reconstruction of paleoenvironmental conditions with respect to the Eurasian continental margin for the last $150 \mathrm{kyr}$. 
In general, the depositional environment through this time period is dominated by terrigenous supply, but with a significant variance related to glacial/interglacial conditions. This varying, but predominantly terrestrially derived sediment-supply via seaice, icebergs, river input, and gravitational transport is also well-reflected in the composition of the sedimentary organic matter and is obvious from very low $\mathrm{HI}(<100 \mathrm{mg} \mathrm{HC} / \mathrm{g}$ TOC$)$ and significantly higher long-chain $n$-alkane concentrations characteristic for TOM (up to $6 \mu \mathrm{g} / \mathrm{g}$ Sed.) (cf. Fig. 4). Although the proportion of MOM cannot be quantitatively determined by a single marker, the pattern of distribution of short-chain $n$-alkanes and chlorins along the northern Barents Sea margin seems to reflect glacial/interglacial variations with higher values during warmer and lower values during colder periods (except event I $\left(^{*}\right)$ and MIS 4, cf. Fig. 13; Knies and Stein, 1998). Furthermore, fluctuations in those "MOM records" show a distinct decrease in concentration from the western to the eastern Eurasian continental margin during the last $150 \mathrm{kyr}$ (Fig. 13). Extremely low concentrations on the northern Kara Sea margin may reflect variations of significant environmental changes from an ice-edge upwelling regime with seasonally ice-free conditions during

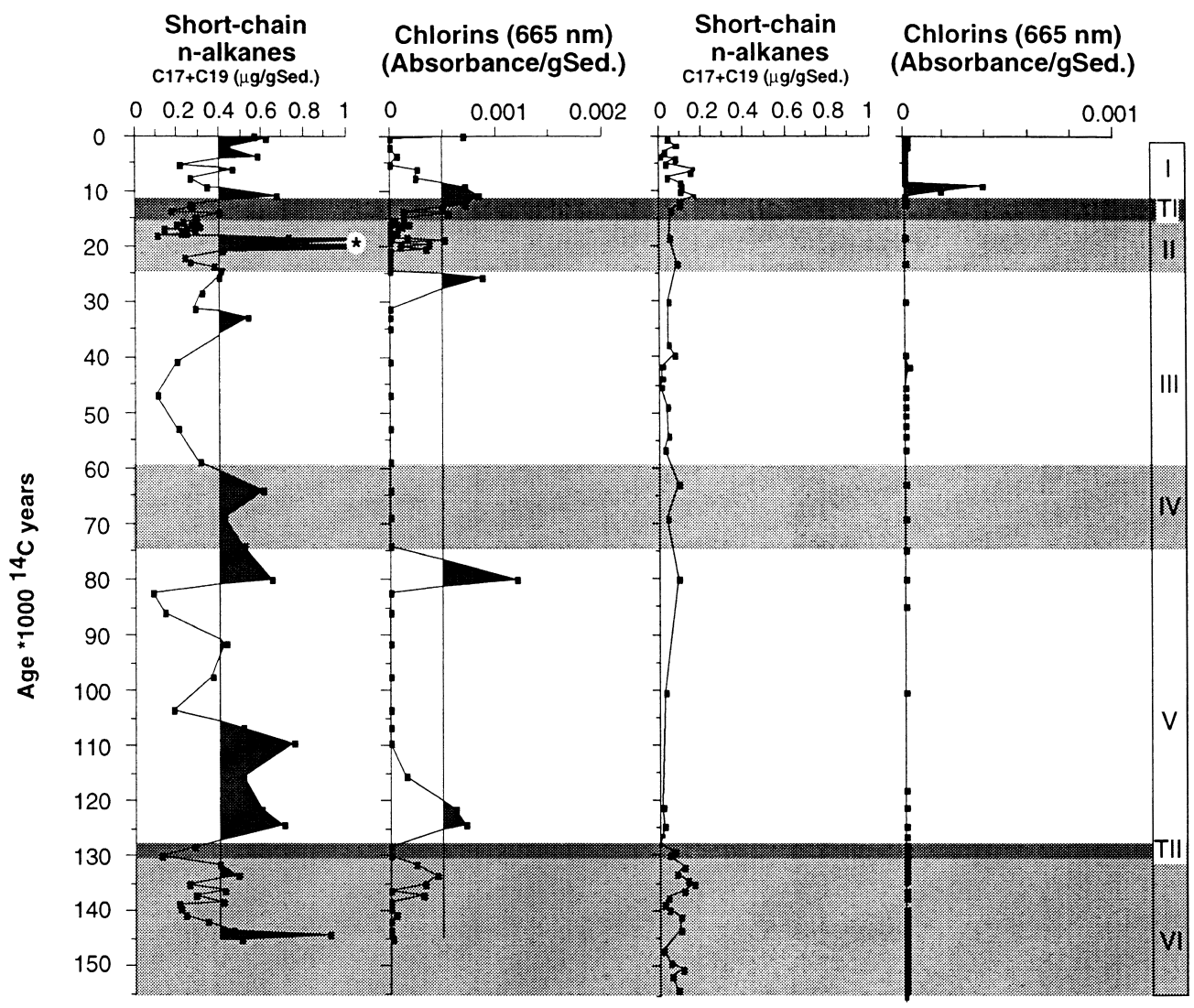

PS2138-1

PS2741-1

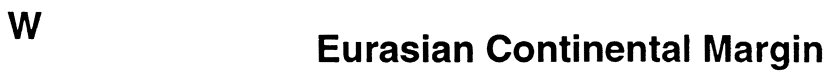

E

Fig. 13. Short-chain $n$-alkane concentrations $\left(\mu \mathrm{g} / \mathrm{g}\right.$ Sed.) and chlorine absorbance $(665 \mathrm{~nm})$ along the Eurasian continental margin vs. ${ }^{14} \mathrm{C}$ ages. Asterisk marks high accumulation of MOM during event I described in detail by Knies and Stein (1998). 
warm summers on the western margin to a permanent and stable sea-ice cover with very low surfacewater productivity changes on the eastern margin (cf. Fig. 13).

\subsubsection{Glacials}

Peak glacials MIS 6 and MIS 2 reveal distinct differences between the western and the eastern margin. Highest accumulation rates of TOC (up to 0.45 $\mathrm{g} \mathrm{cm}^{-2} \mathrm{kyr}^{-1}$ ) and biogenic carbonate peak values (up to 15\%) along the northern Barents Sea margin during MIS 6 and MIS 2 reflect intensive terrestrial supply by advancing ice-sheets and seasonally open-water conditions triggered by subsurface inflow of Atlantic water and coastal polynyas (cf. Fig. 4) (Knies et al., 1999). This is conform with warming episodes described for the western Svalbard margin (Hebbeln et al., 1994; Dokken and Hald, 1996) and implies huge amounts of moisture evaporating to support the final build-up of the SBIS during peak glacials. Enhanced preservation of MOM, indicated by low short-chain $n$-alkanes and chlorine concentrations, which could confirm seasonally ice-free conditions, is almost diminished due to intense flux of siliciclastic and TOM (Fig. 13).

On the northern Kara Sea margin, MIS 6 reflects the assumed colder climate, with extensive ice-sheets onto the shelf and massive sea-ice coverage (DonnWilliam et al., 1962; Arkhipov et al., 1986a,b; Vogt, 1986). The first hints for a perennial sea-ice cover during MIS 6 rather than seasonally open-water conditions were obtained from the lack of foraminifera and neglectable amounts of MOM (cf. Figs. 4 and 13). High contents of kaolinite and smectite, presumably supplied by submarine meltwater discharge from an expanded ice-sheet to the northern Kara Sea margin (cf. Vogt, 1997), may indicate lateral transport processes enforced by the Coriolis effect rather than a vertical flux via sea-ice melting or productivity changes (Fig. 11).

In accordance with Darby et al. (1997) and Nørgaard-Pedersen et al. (1998), we interpret the low total flux rates at the Kara Sea margin during late MIS 3 and MIS 2 as indicative of a closely packed sea-ice cover, in contrast to the more seasonal sea-ice coverage at the western margin (cf. Fig. 7). Lowered sea level and more or less exposed and glacier-free Eurasian shelves during peak glacial periods proba- bly reduced entrainment of sediment into sea-ice, sediment supply via icebergs and/or meltwater discharge. However, moderate contents of biogenic carbonate (up to $4 \%$ ) reflect open-water conditions from time to time (Fig. 4). It seems possible that a weak advection of subsurface Atlantic-derived water masses as observed on the northern Barents Sea margin, reached the eastern margin and triggered planktonic productivity by sea-ice melting and nutrient supply. These would support the hypothesis by Dokken and Hald (1996) that each Heinrich event between MIS 4 and MIS 2 in the North Atlantic could have forced Atlantic surface-water to penetrate further north into the Arctic Ocean and thus support the formation of seasonally ice-free waters along the northern Kara Sea margin. However, the restricted ice growth on Severnaya Semlya for the entire period does not indicate enough moisture-bearing storms to have caused a build-up and decay of ice-sheets as occurred along the western Scandinavian and Barents Sea margin.

These results from the marginal areas of the ice-covered Arctic Ocean were not observed in the central parts by Markussen et al. (1985), Cronin et al. (1994), Stein et al. (1994a; c) and NørgaardPedersen et al. (1998) assuming very restricted productivity during the late glacial due to extensive sea-ice coverage. An exception exist in the Amerasian Basin where higher abundances of planktonic foraminifera between 28 an $24{ }^{14} \mathrm{C}$ kyr indicate a brief interstadial, which could further indicate a close connection to the periodically ice-free events along the Eurasian continental margin (Darby et al., 1997).

During MIS 4 seasonally open-water conditions occurred along the western and northern Svalbard margin (Pagels, 1991; Dokken and Hald, 1996; Knies et al., 1999), as well as in the Fram Strait (Gard, 1987; Hebbeln and Wefer, 1997). In the central Arctic Ocean, however, MIS 4 is interpreted as a peak glacial period with low seasonal variations in sea-ice coverage and diminished planktonic productivity (Nørgaard-Pedersen et al., 1998). Along the Eurasian continental margin decreasing amounts of MOM from the western to the eastern margin (Fig. 13) could indicate both the decreasing influence of Atlantic water and the transition from the marginal ice zone with enhanced productivity in the west to a more or less permanent ice cover in the east. 


\subsubsection{Interglacials}

Distinct peaks in MOM input during substages 5.5, 5.1, and Early Holocene might indicate an environment comparable to the recent situation with nutrient supply by ice-edge upwelling, sea-ice melting, and Atlantic water inflow, at least close to the Franz Victoria Trough (Fig. 13). On the northern Kara Sea margin, enhanced MOM accumulation indicated by chlorine peak values may suggest relatively higher proportions of open-water conditions and could correspond to the climatic optimum during Early Holocene and even indicate probably the warmest time interval during the last $150 \mathrm{kyr}$ along the northern Severnaya Semlya margin (Fig. 13) (cf. Hahne and Melles, 1997). As in the northern Barents Sea, carbonate dissolution probably limits the interpretation of the paleoenvironment during interglacials and deglacials (cf. Fig. 4). A strong influence of highly saline and oxygen-enriched water masses with increased metabolic $\mathrm{CO}_{2}$-concentrations produced on the seasonal ice-free shallow Eurasian shelves is assumed for the interglacials (cf. Knies et al., 1999). Descending in troughs and depressions on the eastern and northern Barents Sea and flowing as boundary currents along the Eurasian margin, this could support $\mathrm{CaCO}_{3}$ dissolution even on the northern Kara Sea margin (Steinsund and Hald, 1994; Anderson, 1995; Schauer et al., 1997). During deglacial periods with rapid ice ablation (MIS 4.13 transition, Terminations I and II), dissolution spikes are probably caused by a distinct decrease in ventilation and exchange of bottom waters due to stabilisation of the water column by development of extensive meltwater lids at the surface (Henrich, 1989, 1998 for an overview). Increased accumulation of MOM along the northern Barents Sea margin during late Termination I reflects a higher surface-water productivity due to permanent intrusion of Atlantic water and high suspension load released by melting sea-ice (Knies and Stein, 1998). The sea-ice signal is supported by highest concentrations of long-chain $n$-alkanes with relatively high CPI values (up to 4.5) (Fig. 4) indicating rather fresh TOM-input, as well as with highest smectite concentrations (up to 20\%) (Fig. 9). This suggest the western Laptev or eastern Kara Sea as most probable source area (Wahsner et al., 1999). During initial deglaciation and the subsequent rise in the sea level, the flooding of the formerly exposed shelves resulted in large-scale erosion and distinctly increased supply of fresh TOM and smectite-rich sediments (Figs. 4 and 9) (Stein and Fahl, 1999). These materials were entrained into sea-ice, transported through the eastern Arctic Ocean and finally released in the marginal ice zone between the Fram Strait and Franz Josef Land (cf. Pfirman et al., 1997). High smectite contents and significantly higher long-chain $n$-alkanes concentrations (up to $6.2 \mu \mathrm{g} / \mathrm{g}$ Sed.) on the northern Kara Sea margin during MIS 1 (Fig. 4), however, can be explained by seasonal formation of dense brines on the flooded shelves that cascaded downslope and, probably as contour current, carried fine-grained suspension along the continental slope (Fig. 4). Deposition occurs where velocities are low enough to allow settling and cause high accumulation rates (Fig. 7).

Taking into account all the available information described above, it becomes obvious that the environmental conditions over the last $150 \mathrm{kyr}$ differed totally in the western and eastern Eurasian continental margin. However, the transition from the ice-edge upwelling regime with at least subsurface Atlantic water influence in the west to the more stable sea-ice cover in the east has not much changed over the last $150 \mathrm{kyr}$.

\section{Conclusions}

Environmental changes over $150 \mathrm{kyr}$ have been studied along the Eurasian continental margin. Seasonally, open-water conditions associated with Atlantic water advection, extended at least to the Franz Victoria Trough, and, combined with moisture bearing storms and low summer insolation, had a major influence on the final ice build-up during glacial MIS 6 and MIS 2 on the western Eurasian margin. Large ice-sheet fluctuations on the western Eurasian margin, contemporaneous with major Laurentide ice-sheet surging events (Heinrich events) between MIS 4 and MIS 2, suggest a link of ice-sheet dynamics in response to short-term rises in sea level caused by Laurentide surge and/or an external forcing by climate or climate-related mechanisms (Bond and Lotti, 1995; McCabe and Clark, 1998).

In low-precipitation areas of eastern Eurasia, the local source of moisture for the atmosphere was 
probably restricted due to a more or less closely packed sea-ice cover over the whole time span. Ice advance onto the shelf occurred during MIS 6 and MIS 4 and follows distinct interglacial periods. A diamicton of Middle Weichselian age indicates a grounding ice-sheet on the shallow shelf north of Severnaya Semlya in at least $340 \mathrm{~m}$ water depth. This confirms the model of an asymmetry of the cryosphere in Eurasia during the last glaciation with a maximally extended ice-sheet along the western margin and an ice-sheet of limited size along the eastern margin. It suggests that during the initial cooling following MIS 5, and probably MIS 7, the combined effect of sustained inflow of Atlantic water into the Arctic Ocean and eastward penetration of moisture-bearing cyclones supported major ice buildup during Saalian and Middle Weichselian glaciation.

Generally, the environmental conditions reflect a gradient from a more or less stable ice-edge upwelling regime with at least subsurface Atlantic water inflow along the western margin to a permanent sea-ice cover with low surface-water productivity on the eastern margin over the last 150 kyr. Advection of surface and/or subsurface Atlantic water masses coupled with seasonally ice-free conditions occurred along the western margin during the last $150 \mathrm{kyr}$. Sustained periods of open water were largely restricted to substages 5.5, 5.1, and the Holocene. Signals of open-water conditions along the eastern margin are insignificant. Slightly higher production of planktonic foraminifera, probably due to Atlantic water inflow occurred between 38 and $12{ }^{14} \mathrm{C} \mathrm{kyr}$ and corresponds with periodically Atlantic water advection penetrating into the Arctic Ocean. However, marine organic proxies indicate a continuous decrease of surface-water productivity from the western to the eastern Eurasian continental margin due to a more extensive sea-ice cover over the last $150 \mathrm{kyr}$.

\section{Acknowledgements}

We thank the captain and the crew of the $\mathrm{R} / \mathrm{V}$ Polarstern for cooperation during the expeditions ARK VIII/1 and ARK XI/I. G. Meyer, G. Traue, L. Schönicke, J. Marie-Nadeau, and D. Grootes are greatly acknowledged for stable isotope analysis and
AMS ${ }^{14} \mathrm{C}$ measurements. For technical assistance in the geochemical laboratory, we sincerely thank $M$. Siebold and K. Fahl. We acknowledge N. NørgaardPedersen for discussion and supply of unpublished DBD-data. For discussions of data and helpful comments of earlier versions of this work, we thank D. Hebbeln, J. Hefter, and J. Matthiessen. In addition to M. Arthur, Trond Dokken and one anonymous reviewer, discussions with John Inge Svendsen were all very informative and helpful.

\section{References}

Aagaard, K., Carmack, E.C., 1989. The role of sea ice and other fresh water in the arctic circulation. J. Geophys. Res. 94 (C10), 14485-14498.

Aagaard, K., Carmack, E.C., 1994. The Arctic Ocean and climate: a perspective. In: Johannessen, O.M., Muench, R.D., Overland, J.E. (Eds.), The Polar Oceans and their Role in Shaping the Global Environment: The Nansen Centennial Volume, Vol. 85. Geophysical Monograph, American Geophysical Union, Washington, DC, pp. 5-20.

Andersen, E.S., Dokken, T.M., Elverhøi, A., Solheim, A., Fossen, I., 1996. Late Quaternary sedimentation and glacial history of the western Svalbard margin. Mar. Geol. 133, 123-156.

Anderson, L.G., 1995. Chemical oceanography of the Arctic and its shelf seas. In: Smith, W.O., Grebmeier, J.M. (Eds.), Arctic Oceanography: Marginal Ice Zones and Continental Shelves, Coastal and Estuarine Studies, Vol. 49. American Geophysical Union, Washington, DC, pp. 183-202.

Arkhipov, S.A., Isayeva, L.L., Bespaly, V.G., Glushkova, O.Y., 1986a. Glaciation of Siberia and northeast USSR. Quat. Sci. Rev. 5, 463-474.

Arkhipov, S.A., Bespaly, V.G., Faustova, M.A., Glushkova, O.Y., Isayeva, L.L., Velichko, A.A., 1986b. Ice-sheet reconstructions. Quat. Sci. Rev. 5, 475-483.

Bard, E., Arnold, M., Hamelin, B., 1992. Present status of the radiocarbon calibration of the Late Pleistocene. 4th International Conference on Paleoceanography, Res. Center for Marine Geosci., GEOMAR, Kiel, Germany, Rep. 15, pp. 52-53 (abstract).

Baumann, K.-H., Lackschewitz, K.S., Mangerud, J., Spielhagen, R.F., Wolf-Welling, T.C.W., Henrich, R., Kassens, H., 1995. Reflection of Scandinavian ice sheet fluctuations in Norwegian Sea sediments during the past 150000 years. Quat. Res. 43, 185-197.

Birkenmajer, K., 1989. The geology of Svalbard, the western part of the Barents Sea, and the continental margin of Scandinavia. In: Nairn, A.E.M., Churkinund, M., Stehli, F.G. (Eds.), The Arctic Ocean. The Ocean Basins and Margins, Vol. 5. Plenum, New York, pp. 265-330.

Biscaye, P.E., 1965. Mineralogy and sedimentation of recent deep-sea clays in the Atlantic Ocean and adjacent seas and oceans. Geol. Soc. Am. Bull. 76, 803-832. 
Bleil, R., Gard, G., 1989. Chronology and correlation of Quaternary magnetostratigraphy and nannofossil biostratigraphy in Norwegian-Greenland Sea sediments. Geol. Rundsch. 78, 1173-1187.

Blumer, M., Guillard, R.R.L., Chase, T., 1971. Hydrocarbons of marine phytoplankton. Mar. Biol. 8, 183-189.

Bond, G.C., Lotti, R., 1995. Iceberg discharges into the North Atlantic on millennial time scales during the last glaciation. Science 267, 1005-1010.

Bond, G.C., Heinrich, H., Broecker, W., Labeyrie, L., McManus, J., Andrews, J., Huon, S., Jantschik, R., Clasen, S., Simet, C., Tedesco, K., Klas, M., Bonani, G., Ivy, S., 1992. Evidence for massive discharges of icebergs into the North Atlantic ocean during the last glacial period. Nature 365, 143-147.

Bonhommet, N., Babkine, J., 1967. Sur la présence d'aimantations inversées dans la Chaine des Puys. C. R. Acad. Sci. Paris 264, 92-94.

Bray, E.E., Evans, E.D., 1961. Distribution of $n$-paraffins as a clue to recognition of source beds. Geochim. Cosmochim. Acta 22, 2-15.

Broecker, W.S., 1994. Massive iceberg discharges as triggers for global climate change. Nature 372, 421-424.

Carmack, E.C., Macdonald, R.W., Perkin, R.G., Mclaughlin, F.A., Pearson, R.J., 1995. Evidence for warming of Atlantic water in the southern Canadian Basin of the Arctic Ocean: results from the Larsen-93 expedition. Geophys. Res. Lett. 22, 10611064.

Cronin, T.M., Holtz, T.R., Whatley, R.C., 1994. Quaternary paleoceanography of the deep Arctic Ocean based on quantitative analysis of Ostracoda. Mar. Geol. 119, 305-332.

Darby, D.A., Bischof, J.F., Jones, G.A., 1997. Radiocarbon chronology of depositional regimes in the western Arctic Ocean. Deep-Sea Res. 44 (8), 1745-1745.

Denham, C.R., Cox, A., 1971. Evidence that the Laschamp polarity event did not occur 13300-30400 years ago. Earth Planet. Sci. Lett. 13, 181-190.

Denton, G.H., Hughes, T.J., 1981. The Last Great Ice Sheets. Wiley-Interscience, New York, 484 pp.

Denton, G.H., Karlen, W., 1973. Holocene climatic variations their pattern and cause. Quat. Res. 3, 155-205.

Dokken, T.M., Hald, M., 1996. Rapid climatic shifts during isotope stages $2-4$ in the Polar North Atlantic. Geology 24 (7), 599-602.

Donn-William, L., Ferrand, W.R., Ewing, M., 1962. Pleistocene ice volumes and sea-level lowering. J. Geol. 70, 206-214.

Dunayev, N.N., Pavlidis, J.A., 1988. A model of Late Pleistocene glaciation of Eurasiatic Arctic Shelf. In: Kotlyakov, V.M., Sokolov, V.E. (Eds.), Arctic Research - Advances and Prospects, Vol. 2, pp. 70-72.

Eglington, G., Hamilton, R.J., 1967. Leaf epicuticular waxes. Science 156, 1322-1325.

Elverhøi, A., Pfirman, S.L., Solheim, A., Larssen, B.B., 1989. Glaciomarine sedimentation in epicontinental seas exemplified by the northern Barents Sea. Mar. Geol. 85, 225-250.

Elverhøi, A., Andersen, E.S., Dokken, T., Hebbeln, D., Spielhagen, R.F., Svendsen, J.I., Sørflaten, M., Rørnes, A., Hald, M., Forsberg, C.F., 1995. The growth and decay of the Late
Wechselian ice sheet in western Svalbard and adjacent areas based on provenance studies of marine sediments. Quat. Res. 44, 303-316.

Emmermann, R., Lauterjung, J., 1990. Double X-ray analysis of cuttings and rock flour: a powerful tool for rapid and reliable determination of borehole lithostratigraphy. Sci. Drill. 1, 269282.

Espitalié, J., Laporte, J.L., Madec, M., Marquis, F., Leplat, P., Paulet, J., Boutefeu, A., 1977. Méthode rapide de chararcterisation des roches-mere de leur potential petrolier et de leur degre d'évolution. Rev. Inst. Tranc. Petrol. 32, $23-42$.

Fairbanks, R.G., 1989. A 17000-year glacio-eustatic sea level record: influence of glacial melting rates on the Younger Dryas event and deep ocean circulation. Nature 342, 637-642.

Fahl, K., Stein, R., 1997. Modern organic-carbon-deposition in the Laptev Sea and the adjacent continental slope: surface-water productivity vs. terrigenous supply. Org. Geochem. 26 (5/6), 379-390.

Fahl, K., Stein, R., 1999. Biomarkers as organic-carbon-source and environmental indicators in the Late Quaternary Arctic Ocean: "problems and perspectives"'. Mar. Chem. 63 (3-4), 293-309.

Fronval, T., Jansen, E., 1997. Eemian and Early Weichselian (140-60 ka) paleoceanography and paleoclimate in the Nordic seas with comparisons to Holocene conditions. Paleoceanography $12,443-462$.

Fronval, T., Jansen, E., Bloemendal, J., Johnson, S., 1995. Oceanic evidence for coherent fluctuations in Fennoscandian and Laurentide ice sheets on millennium timescales. Nature 374, 443446.

Gard, G., 1987. Late Quaternary calcareous nannofossil biostratigraphy and sedimentation pattern: Fram Strait, Arctica. Paleoceanography 2 (5), 519-529.

Gealy, E.L., 1971. Saturated bulk density, grain density, and porosity of sediment cores from the western Equatorial $\mathrm{Pa}-$ cific: Leg 7, Glomar Challenger. Proc. DSDP Init. Rep. 7, 1081-1104.

Grobe, H., 1987. A simple method for determination of ice rafted debris in sediment cores. Polarforschung 57 (3), 123-126.

Grosswald, M.G., 1993. Extent and melting history of the Late Weichselian ice sheet, the Barents-Kara continental margin. In: Peltier, R. (Ed.), Ice in the Climate System. NATO ASI Series 12. Springer-Verlag, Berlin, pp. 1-20.

Haake, F.W., Plaumann, U., 1989. Late Pleistocene foraminiferal stratigraphy on the Vøring Plateau, Norwegian Sea. Boreas 18 (4), 343-356.

Haake, F.W., Erlenkeuser, H., Pflaumann, U., 1990. Pullenia bulloides (Orbigny) in Sediments of the Norwegian/Greenland Sea and the Northeastern Atlantic Ocean: Paleo-Oceanographic Evidence. BENTHOS '90, Tokai University Press, Sendai, Japan, pp. 235-244.

Hahne, J., Melles, M., 1997. Late- and post-glacial vegetation and climate history of the south western Taymyr Peninsula, central Siberia, as revealed by pollen analysis of a core from Lake Lama. Vegetation History and Archaeobotany 6, 1-8.

Harris, P.G., Rosell-Melé, A., Tiedemann, R., Sarnthein, M., Maxwell, J.R., 1996. Chlorine accumulation rate as a molecu- 
lar indicator of paleoproductivity changes in Quaternary marine sediments. Nature 383, 63-66.

Hebbeln, D., 1992. Wechselian glacial history of the Svalbard area: correlating the marine and terrestrial records. Boreas 21, 295-304.

Hebbeln, D., Wefer, G., 1997. Late Quaternary paleoceanography in the Fram Strait. Paleoceanography 12 (1), 65-78.

Hebbeln, D., Dokken, T., Andersen, E.S., Hald, M., Elverhøi, A., 1994. Moisture supply for northern ice-sheet growth during the Last Glacial Maximum. Nature 370, 357-359.

Henrich, R., 1989. Glacial/interglacial Cycles in the Norwegian Sea: sedimentology, paleoceanography, and evolution of Late Pliocene to Quaternary northern Hemisphere climate. In: Eldholm, O., Thiede, J., Taylor, E., et al. (Eds.), LEG 104 Norwegian Sea. Proc. ODP Scientific Results, Vol. 104, pp. 189-232.

Henrich, R., 1998. Dynamics of Atlantic water advection to the Norwegian-Greenland Sea - a time-slice record of carbonate distribution in the last 300 ky. Mar. Geol. 145, 95-131.

Hibler, III, W.D., 1989. Arctic ice-ocean dynamics. In: Herman, Y. (Eds.), The Arctic Seas, pp. 47-91.

Hollerbach, A., 1985. Grundlagen der Organischen Geochemie. Springer-Verlag, Berlin, 190 pp.

Jasper, J.P., Gagosian, R.B., 1989. Glacial-interglacial climatically forced $\delta^{13} \mathrm{C}$ variations in sedimentary organic matter. Nature 342, 60-62.

Jones, G.A., Keigwin, L.D., 1988. Evidence from Fram Strait $\left(78^{\circ} \mathrm{N}\right)$ for early deglaciation. Nature $336,56-59$.

Keigwin, L.D., Jones, G.A., 1994. Western North Atlantic evidence for millennial-scale changes in ocean circulation and climate. J. Geophys. Res. 99, 12377-12410.

Keigwin, L.D., Jones, G.A., 1995. The marine record of deglaciation from the continental margin off Nova Scotia. Paleoceanography 10, 973-986.

Kleiber, H.P., Niessen, F., 1999. Late Pleistocene paleoriver channels on the Laptev Sea shelf - implications from subbottom profiling. In: Kassens, H., Bauch, H.A., Dmitrenko, I., Eicken, H., Hubberten, H.-W., Melles, M., Thiede, J., Timokhov, L. (Eds.), Land-Ocean Systems in the Siberian Arctic: Dynamics and History. Springer-Verlag, pp. 657-666.

Kleiber, H.P., Knies, J., Niessen, F., in preparation. Timing and extent of the Late Weichselian glaciation in the Franz Victoria Trough, northern Barents Sea. Mar. Geol. (submitted).

Knies, J., 1999. Late Quaternary paleoenvironment along the northern Barents and Kara Sea margin: a multiproxy analysis. Reports on Polar Research, Vol. 304, 150 pp.

Knies, J., Stein, R., 1998. New aspects of organic carbon deposition and paleoceanographic implications along the northern Barents Sea margin during the last 30000 years. Paleoceanography 13 (4), 384-394.

Knies, J., Vogt, C., Stein, R., 1999. Growth and decay patterns of the Svalbard-Barents Sea ice sheet and paleoceanographic evolution during Saalian and Weichselian glaciations. GeoMar. Lett. 18, 195-202.

Köhler, S.E.I., Spielhagen, R., 1992. The enigma of isotope stage 5 in the central Fram Strait. In: Bleil, U., Thiede, J. (Eds.), Geological History of the Polar Oceans: Arctic versus Antarc- tic, Vol. C308. NATO ASI Series, Kluwer Acacemic Publishers, Dordrecht, pp. 489-497.

Laberg, J.S., Vorren, T.O., 1995. Late Weichselian submarine debris flow deposits on the Bear Island Trough Mouth Fan. Mar. Geol. 127, 45-72.

Landvik, J.Y., Bolstad, M., Lycke, A.K., Mangerud, J., Sejrup, H.P., 1992. Weichselian stratigraphy and palaeoenvironments at Bellsund, western Svalbard. Boreas 21, 335-358.

Larsen, E., Mangerud, J., 1990. Marine caves: on-off signals for glaciations. Quat. Int. 3/4, 13-19.

Liestøl, O., 1969. Glacier surges in West Spitsbergen. Can. J. Earth Sci. 6, 895-897.

Lloyd, J.M., Kroon, D., Boulton, G.S., Laban, C., Fallick, A., 1996. Ice rafting history from the Spitsbergen ice cap over the last 200 kyr. Mar. Geol. 131, 103-121.

Løvlie, R., 1989a. Paleomagnetic stratigraphy: a correlation method. Quat. Int. 1, 129-149.

Løvlie, R., 1989b. Paleomagnetic excursions during the last interglacial/glacial cycle: a synthesis. Quat. Int. 3/4, 5-11.

Løvlie, R., Markussen, B., Sejrup, H.P., Thiede, J., 1986. Magnetostratigraphy in three Arctic Ocean sediment cores; arguments for geomagnetic excursions within oxygen isotope stages 2-3. Phys. Earth Planet. Inter. 43, 173-184.

Lubinski, D.J., Korsun, S., Polyak, L., Forman, S.L., Lehman, S.J., Herlihy, F.A., Miller, G.H., 1996. The last deglaciation of the Franz Victoria Trough, northern Barents Sea. Boreas 25, 89-100.

MacAyeal, D.R., 1993. Binge/Purge oscillations of the Laurentide ice sheet as the cause of the North Atlantic's Heinrich events. Paleoceanography 8, 775-784.

Mangerud, J., Gulliksen, S., 1975. Apparent radiocarbon ages of recent marine shells from Norway, Spitsbergen, and Arctic Canada. Quat. Res. 5, 273-296.

Mangerud, J., Svendsen, J.I., 1992. The last interglacial-glacial period on Spitsbergen, Svalbard. Quat. Sci. Rev. 11, 633-664.

Mangerud, J., Jansen, E., Landvik, J.Y., 1996. Late Cenozoic history of the Scandinavian and Barents Sea ice sheets. In: Solheim, A., Riis, F., Elverhøi, A., Faleide, J.J., Jensen, L.N., Cloetingh, S. (Eds.), Impact of Glaciations on Basin Evolution: Data and Models from the Norwegian Margins and Adjacent Basins. Global and Planetary Chance, Special Issue 12 , pp. $11-26$.

Mangerud, J., Dokken, T., Hebbeln, D., Heggen, B., Ingolfsson, O., Landvik, J.Y., Mejdahl, V., Svendsen, J.I., Vorren, T.O., 1998. Fluctuations of the Svalbard-Barents Sea ice sheet during the last 150000 years. Quat. Sci. Rev. 17, 11-42.

Mangerud, J., Svendsen, J.I., Astakhov, V.I., 1999. Age and extent of the Barents and Kara ice sheets in northern Russia. Boreas 1, 46-81.

Markussen, B., Zahn, R., Thiede, J., 1985. Late Quaternary sedimentation in the eastern Arctic Basin: stratigraphy and depositional environment. Palaeogeogr., Palaeoclimatol., Palaeoecol. 50, 271-284.

Martinson, D.G., Pisias, N.G., Hays, J.D., Imbrie, J., Moore, T.C., Shakleton, N.J., 1987. Age dating and the orbital theory of the ice ages: Development of a high-resolution 0 to 300000 years chronostratigraphy. Quat. Res. 27, 1-27. 
McCabe, A.M., Clark, P.U., 1998. Ice-sheet variability around the North Atlantic Ocean during the last glaciation. Nature 392, 373-377.

Meincke, J., Rudels, B., Friedrich, H.J., 1997. The Arctic Ocean-Nordic Seas thermohaline system. ICES J. Mar. Sci. 54, 283-299.

NAD Science Committee, 1992. The Arctic Ocean record: key to global chane (initial science plan of the Nansen Arctic Drilling Program). Polarforschung 161, 102 pp.

Naidu, A.S., Scalan, R.S., Feder, H.M., Goering, J.J., Hameedi, M.J., Parker, P.L., Behrens, E.W., Caughey, M.E., Jewett, S.C., 1993. Stable organic carbon isotopes in sediments of the North Bering-South Chukchi seas, Alaskan-Soviet Arctic shelf. Cont. Shelf Res. 13 (5/6), 669-691.

Niessen, F., Weiel, D., Ebel, T., Hahne, J., Kopsch, C., Melles, M., Musatov, E., Stein, R., 1997. Weichselian glaciations in central Siberia - implications from marine and lacrustrine high resolution seismic profiles and sediment cores. Abstract Volume EUG 9 Conference, Strasbourg (European Union of Geosciences), Terra Nova, Vol. 9, Abstr. Suppl. 1, p. 208.

Nowaczyk, N., Antonow, M., 1997. High-resolution magnetostratigraphy of four sediment cores from the Greenland Sea - identification of the Mono Lake excursion, Laschamp and Biwa I/Jamaica geomagnetic polarity events. Geophys. J. Int. 131, 310-324

Nowaczyk, N.R., Baumann, M., 1992. Combined high-resolution magnetostratigraphy and nannofossil biostratigraphy for Late Quaternary Arctic Ocean sediments. Deep-Sea Res. 39, 567601.

Nowaczyk, N., Knies, J., 1999. Magnetostratigraphic results from the eastern Arctic Ocean - AMS ${ }^{14} \mathrm{C}$ ages and relative paleointensity data of the Mono Lake and Laschamp geomagnetic events. Geophys. J. Int., in press.

Nowaczyk, N.R., Fredrichs, T.W., Eisenhauer, A., Gard, G., 1994. Magnetostratigraphic data from Late Quaternary sediments from the Yermak Plateau, Arctic Ocean: evidence for four geomagnetic polarity events within the last $170 \mathrm{ka}$ of the Brunshes Chron. Geophys. J. Int. 117, 453-471.

Nørgaard-Pedersen, N., Spielhagen, R.F., Thiede, J., Kassens, H., 1998. Central Arctic surface ocean environment during the past 80000 years. Paleoceanography 13, 193-204.

Oppo, D.W., Lehman, S.J., 1995. Suborbital timescale variability of North Atlantic deep water during the past 200000 years. Paleoceanography 10, 901-910.

Pagels, U., 1991. Sedimentologische Untersuchungen und Bestimmungen der Karbonatlösung in spätquartären Sedimenten des östlichen Arktischen Ozeans. Geomar. Report, Vol. 10. Geomar, Kiel, 106 pp.

Pavlidis, Yu.A., Dunayev, N.N., Shecherbakov, F.A., 1997. The Late Pleistocene palaeogeography of Arctic Eurasian shelves. In: Velitchko, A.A., Dolukhanov, P.M., Rutter, N.W., Catto, N.R. (Eds.), Quaternary of Northern Eurasia: Late Pleistocene and Holocene Landscapes, Stratigraphy and Environments. Quat. Int. 41/42, 3-9.

Pfirman, S.L., Solheim, A., 1989. Subglacial meltwater discharge in the open marine tidewater glacier environment: observations from Nordaustlandet. Mar. Geol. 86, 283-319.
Pfirman, S.L., Bauch, D., Gammelsrød, T., 1994. The northern Barents Sea: water mass distribution and modification. In: Johannessen, O.M., Muench, R.D., Overland, J.E. (Eds.), The Polar Oceans and their Role in Shaping the Global Environment: The Nansen Centennial Volume, Vol. 85. Geophysical Monograph, American Geophysical Union, Washington, DC, pp. 77-94.

Pfirman, S.L., Colony, R., Nürnberg, D., Eicken, H., Rigor, I., 1997. Reconstructing the origin and trajectory of drifting Arctic sea ice. J. Geophys. Res. 102 (C6), 12575-12586.

Polyak, L., Solheim, A., 1994. Late- and post-glacial environments in the northern Barents Sea west of Franz Josef Land. Polar Res. 13 (2), 197-207.

Polyak, L., Forman, S.L., Herlihy, F.A., Ivanov, G., Krinitsky, P., 1997. Late Weichselian deglacial history of the Svyataya (Saint) Anna Trough, northern Kara Sea, Arctic Russia. Mar. Geol. 143 (1/4), 169-188.

Rachor, E. (Eds.), 1992. Scientific Report of RV "Polarstern", Cruise ARK-VIII/2. Reports on Polar Research, Vol. 115, $150 \mathrm{pp}$.

Rachor, E. (Eds.), 1997. Scientific Report of RV "Polarstern", Cruise ARK-XI/1. Reports on Polar Research, Vol. 226, 157 pp.

Romankevich, E.A., 1984. Geochemistry of Organic Matter in the Ocean. Springer-Verlag, 334 pp.

Rosell-Melé, A., Koc, N., 1997. Paleoclimatic significance of the stratigraphic occurrence of photosynthetic biomarker pigments in the Nordic Seas. Geology 25, 49-52.

Rosell-Melé, A., Maslin, M.A., Maxwell, J.R., Schaeffer, P., 1997. Biomarker evidence for Heinrich events. Geochim. Cosmochem. Acta 61 (8), 1671-1678.

Ruddiman, W.F., McIntyre, A., 1981. Oceanic mechanisms for amplification of the 23000-year ice-volume cycle. Science 212, 617-627.

Ruddiman, W.F., McIntyre, A., Niebler-Hunt, V., Durazzi, J.T., 1980. Oceanic evidence for the mechanism of rapid northern Hemisphere glaciation. Quat. Res. 13, 33-64.

Rudels, B., Jones, E.P., Anderson, L.G., Kattner, G., 1994. On the intermediate depth waters of the Arctic Ocean. In: Johannessen, O.M., Muench, R.D., Overland, J.E. (Eds.), The Polar Oceans and their Role in Shaping the Global Environment: The Nansen Centennial Volume, Vol. 85. Geophysical Monograph, American Geophysical Union, Washington, DC, pp. 33-46.

Schauer, U., Muench, R.D., Rudels, B., Timokhov, L., 1997. Impact of eastern Arctic shelf waters on the Nansen Basin intermediate layers. J. Geophys. Res. 102 (C2), 3371-3382.

Schneider, D.A., Backman, J., Curry, W.B., Possnert, G., 1996. Paleomagnetic constraints on sedimentation rates in the eastern Arctic Ocean. Quat. Res. 46, 62-71.

Schubert, C.J., Stein, R., 1997. Lipid distribution in surface sediments from the eastern central Arctic Ocean. Mar. Geol. 138, 11-25.

Smith, J.D., Foster, J.H., 1969. Geomagnetic reversal in Brunhes normal polarity Epoch. Science 163, 565-567.

Spielhagen, R.F., Bonani, G., Eisenhauer, A., Frank, M., Frederichs, T., Kassens, H., Mangini, A., Nowaczyk, N.R., 
Nørgaard-Pedersen, N., Schäper, S., Stein, R., Thiede, J., Tiedemann, R., Wahsner, M., Kubik, P.W., 1997. Arctic Ocean evidence for Late Quaternary initiation of northern Eurasian ice sheets. Geology 25 (9), 783-786.

Stein, R., 1991. Accumulation of organic carbon in marine sediments. Lecture Notes in Earth Sciences, Vol. 34. SpringerVerlag, Berlin, 217 pp.

Stein, R., Fahl, K., 1999. Holocene accumulation of organic carbon at the Laptev Sea continental margin (Arctic Ocean): sources, pathways, and sinks. Geo-Mar. Lett., in press.

Stein, R., Schubert, C., Vogt, C., Fütterer, D.K., 1994a. Stable isotope stratigraphy, sedimentation rates, and salinity changes in the Latest Pleistocene to Holocene eastern central Arctic Ocean. Mar. Geol. 119, 333-355.

Stein, R., Grobe, H., Wahsner, M., 1994b. Organic carbon, carbonate, and clay mineral distributions in eastern central Arctic Ocean surface sediments. Mar. Geol. 119, 269-285.

Stein, R., Nam, S.-I., Schubert, C., Vogt, C., Fütterer, D.K., Heinemeier, J., 1994c. The Last Deglaciation event in the eastern central Arctic Ocean. Science 264, 692-696.

Steinsund, P.I., Hald, M., 1994. Recent calcium carbonate dissolution in the Barents Sea: paleoceanographic applications. Mar. Geol. 117, 303-316.

Stoner, J.S., Channell, J.E.T., Hillaire-Marcel, C., 1996. The magnetic signature of rapidly deposited detrital layers from the deep Labrador Sea: relationship to North Atlantic Heinrich layers. Paleoceanography 11, 309-325.

Stuiver, M., Reimer, P.J., 1993. Extended ${ }^{14} \mathrm{C}$ data base and revised CALIB $3.0{ }^{14} \mathrm{C}$ age calibration program. Radiocarbon $35,215-230$.

Sudgen, D.E., 1982. Arctic and Antarctic - A Modern Geographical Synthesis. Blackwell Publ., Oxford, 472 pp.

Svendsen, J.I. et al., 1999. Maximum extent of the Eurasian ice sheets in the Barents and Kara Sea region during the Weichselian. Boreas 1, 234-242.

Tissot, B.P., Welte, D.H., 1984. Petroleum Formation and Occurrence. Springer-Verlag, Berlin, $699 \mathrm{pp}$.

Van Andel, T.H., Heath, G.R., Moore, T.C., 1975. Cenozoic history and paleoceanography of the central Equatorial Pacific. Mem. Geol. Soc. Am. 143, 134 pp.
Velitchko, A.A., Kononov, Y.M., Faustova, M.A., 1997. The last glaciation of Earth: size and volume of ice-sheets. In: Velitchko, A.A., Dolukhanov, P.M., Rutter, N.W., Catto, N.R. (Eds.), Quaternary of Northern Eurasia: Late Pleistocene and Holocene Landscapes, Stratigraphy and Environments. Quat. Int. 41/42, 43-51.

Velitchko, A.A., Dolukhanov, P.M., Rutter, N.W., Catto, N.R. (Eds.), 1997. Quaternary of Northern Eurasia: Late Pleistocene and Holocene Landscapes, Stratigraphy and Environments. Quat. Int. 41/42.

Vinje, T., 1977. Sea Ice Conditions in the European Sector of the Marginal Seas of the Arctic 1966-1975. Nor. Polarinst. Aarb., pp. 164-174.

Vinje, T., 1985. Sea ice distribution 1971-1980. Nor. Polarinst. Skr. 179D, 12-20.

Vogt, P.R., 1986. Seafloor, topography, sediments, and paleoenvironments. In: Hurdle, B.G. (Ed.), The Nordic Seas. SpringerVerlag, New York, pp. 237-410.

Vogt, C., 1997. Regional and temporal variations of mineral assemblages in Arctic Ocean sediments as climatic indicator during glacial/interglacial changes. Reports on Polar Research, Vol. 251, 309 pp.

Wagner, T., 1993. Organisches material in pelagischen sedimenten: glaziale/interglaziale variationen im Europäischen Nordmeer. Ber. Sonderfor-Schungsbereich 313 (42) 138 pp.

Wagner, T., Henrich, R., 1994. Organo- and lithofacies of glacial-interglacial deposits in the Norwegian-Greenland Sea: responses to paleoceanographic and paleoclimatic changes. Mar. Geol. 120, 335-364.

Wahsner, M., Müller, C., Stein, R., Ivanov, G., Levitan, M., Shelekova, E., Tarasov, G., 1999. Clay mineral distributions in surface sediments from the central Arctic Ocean and the Eurasian continental margin as indicator for source areas and transport pathways - a synthesis. Boreas 1, 215-234.

Weiel, D., 1997. Paläozeanographische Untersuchungen in der Vilkitsky Straße und östlich von Severnaya Zemlya mit sedimentologischen und geophysikalischen Methoden. Unpublished Diploma Thesis, University of Köln, 138 pp. 